料 $\mathbf{O}$ 九石版使十六九百一立十增 $\mathbf{0}$

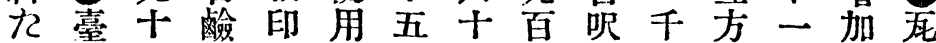

る灣二製刷工馬四六餘兵吹萬し斯

\& の哩造用業力口十の百に七來需

の製三用、種、四增八上干 3 用

澤紙干等機自街機、加十れ立本向

山業二に械は燈關燈な九 万方年增

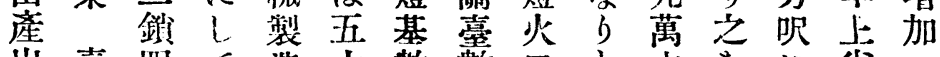

出臺四 $\tau$ 造十數數口孔立存江坐

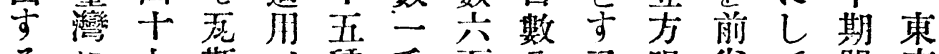

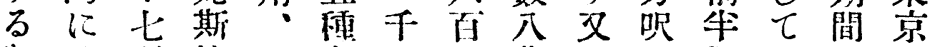

在は哩管發火五十英车稌期一に节

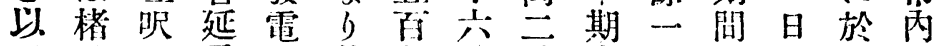

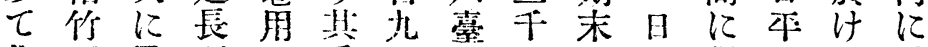

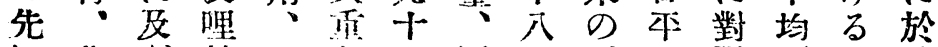

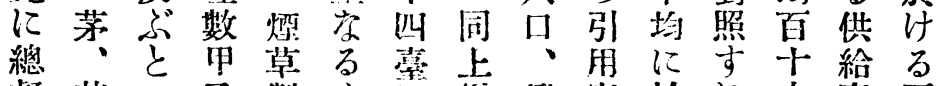

督其八乙製名に䳡燈家於记六高死

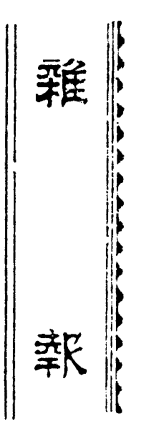

雜

府ら、枝造のし力料数てば萬は斯

は他管用はて兰吼總五三の

箱製活死平數一萬高百億需

義紙計精版斯宍九萬分に至角

聽の三米、機百千卉千於干千は

下原百用石關四百干六七三三縊

○整にのはを卸尔は製上のるて草

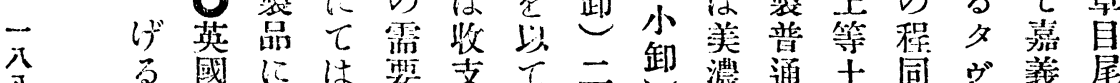

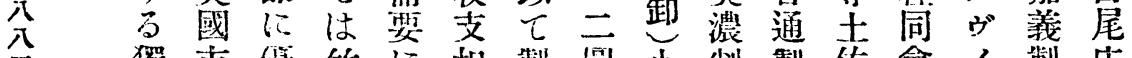

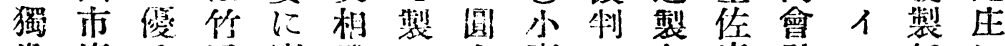

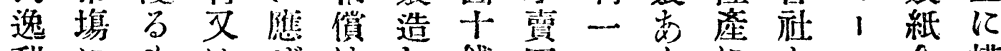

甜にもはぜはし錢四ょ号によン合模

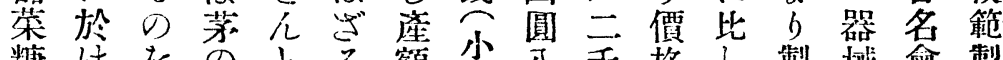

糖けを劣とる額小分格し製械會製

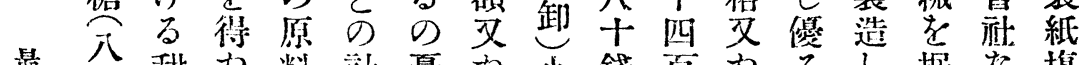

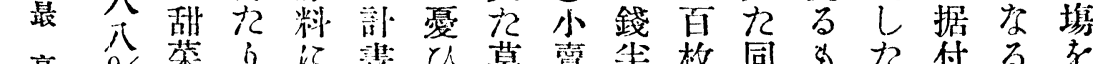

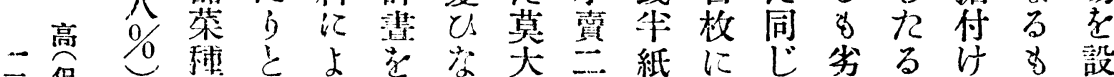

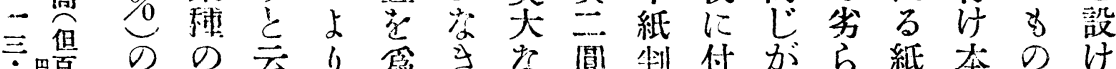

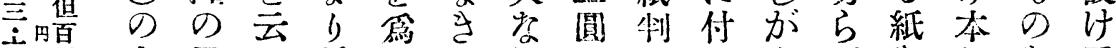

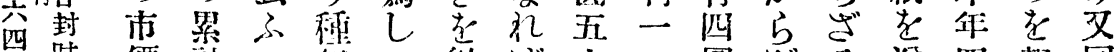

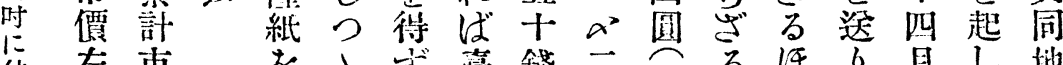

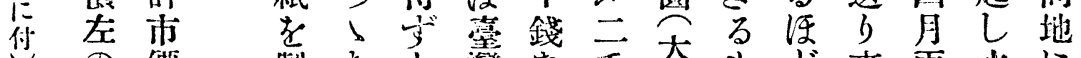

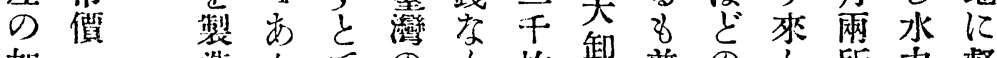

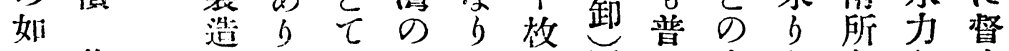

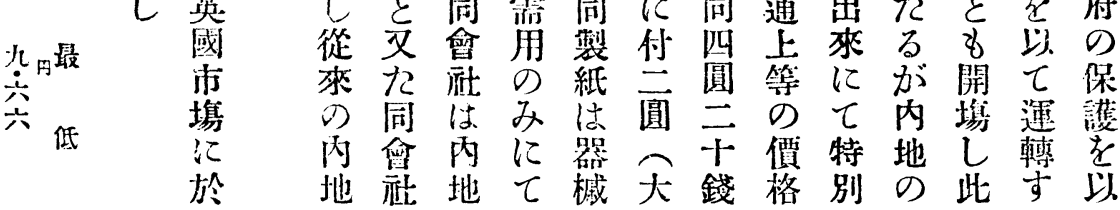

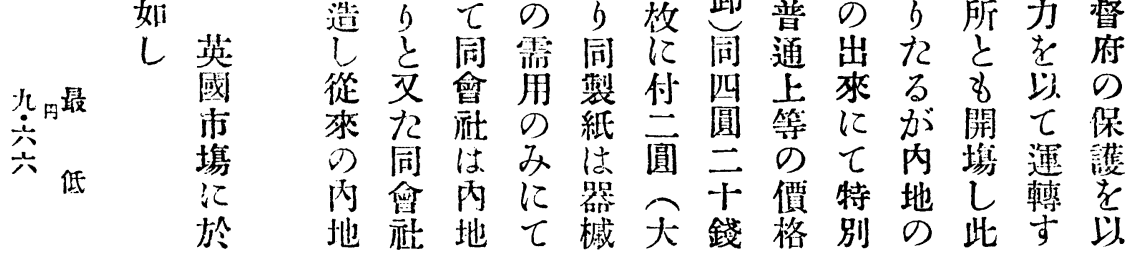




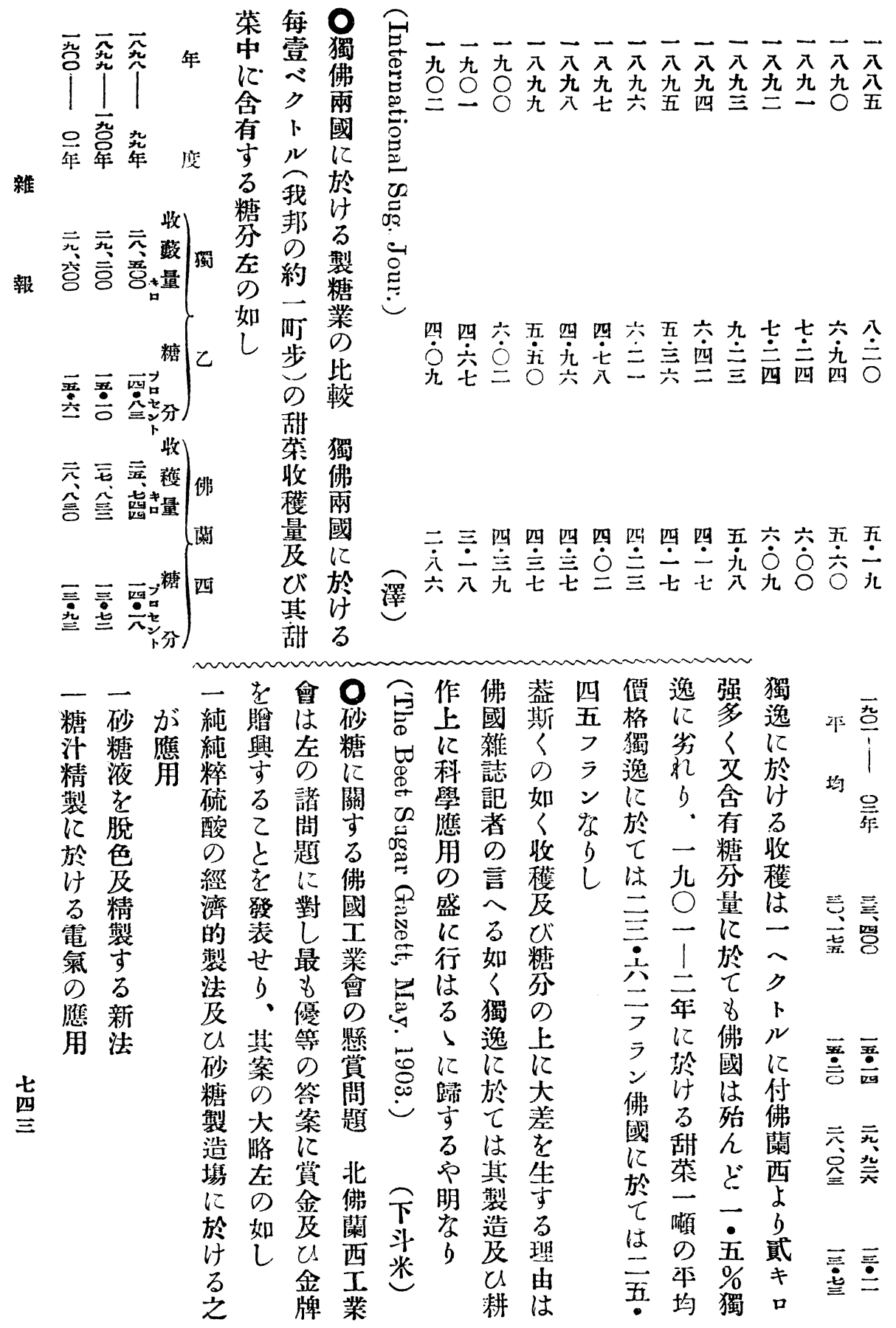




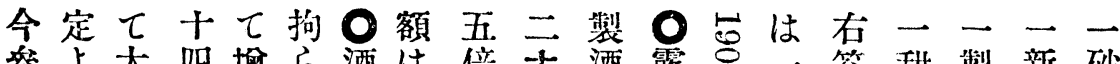
參よ大四增ら酒は倍十酒露怘一答甜製新砂

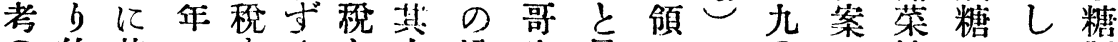
の約其一寺去と大增宛自旦 $\bigcirc$ 糖工製

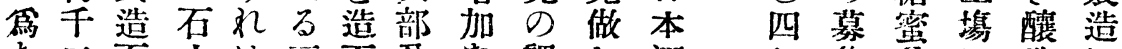
あ三石十は兰石分な課し酒年焦莨に造に

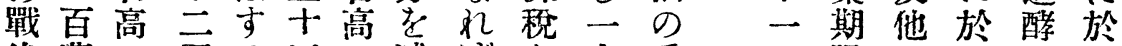
後萬に圆る四减ばを布重月限のけ母て

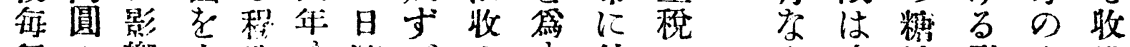

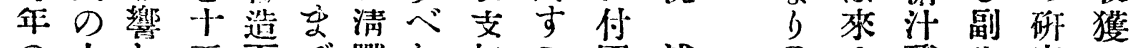
の大し无石で戰し相乙國浦宁る醇生究を

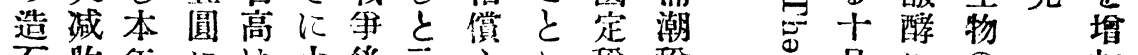

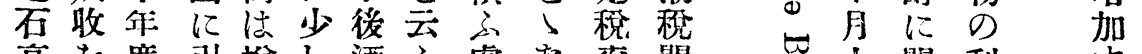
高老度引增し酒之處交關若十關利蓑

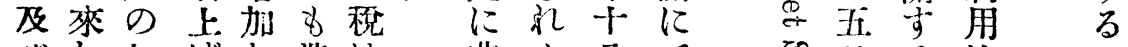
びし如げし造は非り元て こ五る法の

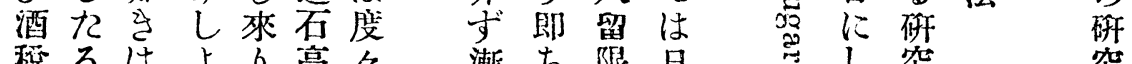
税るはょ，高名漸方限旦究

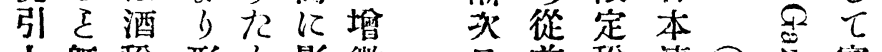

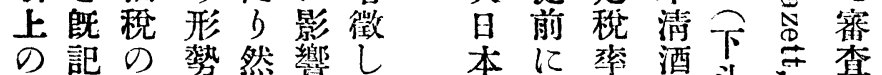

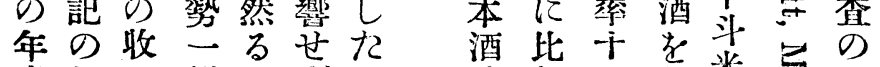

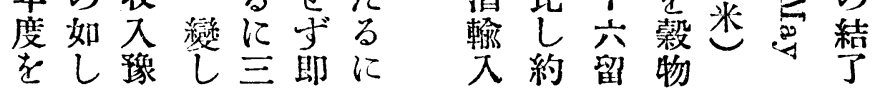

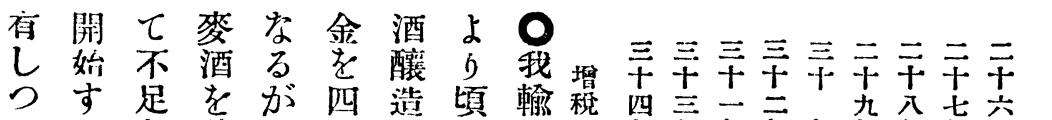
示

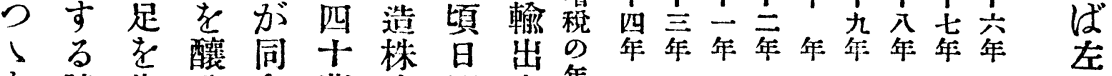
あ曉告造會 萬式膠麥年

るにく”し 而: 弗會州酒茫

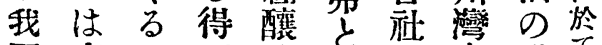
國南如べ造霹設毒勁盗

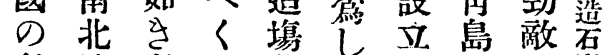

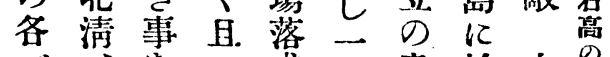
ビ、劣つ成根畫於去特

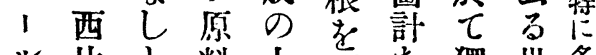

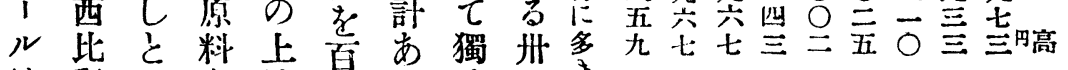

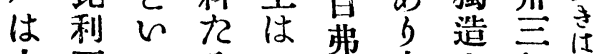
大㰳人る一京本入年見

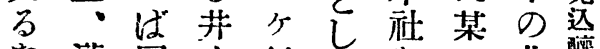

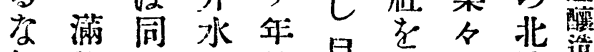
打州泣は約早上の清遥 敖西㤎頗㫐株海發事多 を圆愈る英株に起變吉 受に名住五金置老监因

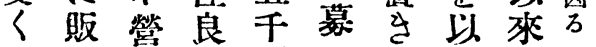
る路業に石集凟元我 にを老しの中本秋國

四四四四呬四罗三三

八三三六三七 七五五五十九二四邀 九公至九旯 六尤三 $\dot{0} \dot{0}$ 尤石 如 報 过 D 如 稚 , 


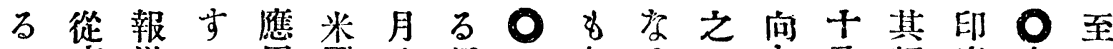
乙来道侖威八新 良るにあ分額度牛る

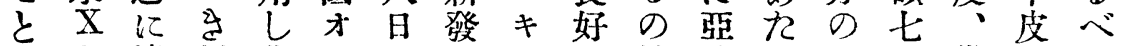
は光據新舊 、を明ス缺げ品七十解のし

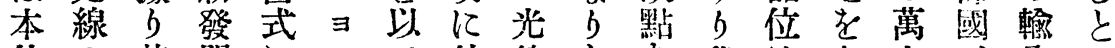
件の其明に、て 付線と市我は占㫐、入乞

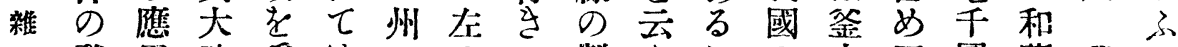
發用䀩丽はシの シ 製ふにの山五圓䉒我

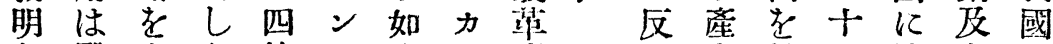

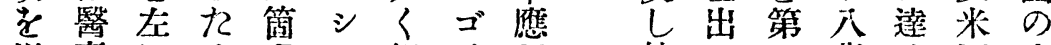
報以事にる当子報駐角韓に一萬セ國牛 七 界報者を香在國係と三引等皮

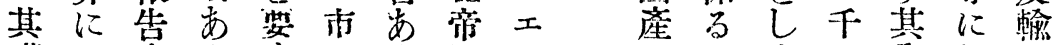

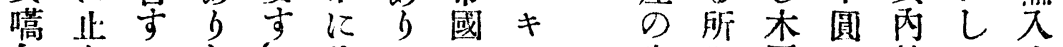

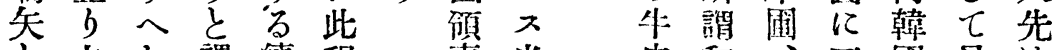

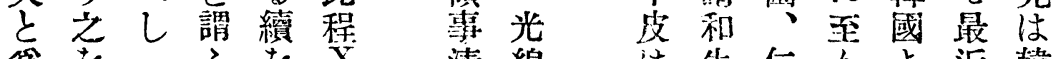

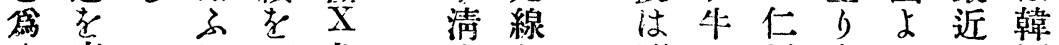
す産因四光水艺形の川监与の國

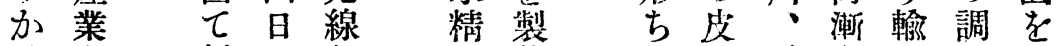
故上 新間艺 三革 大ほ元次入查声 にに聞に製郎に汧山增す市にと

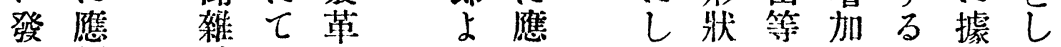
明角誌終法方肺唙ののののれ支 者すの活去す最小座傾はば那

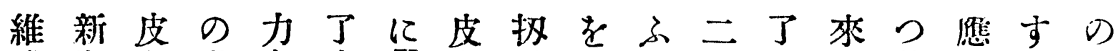

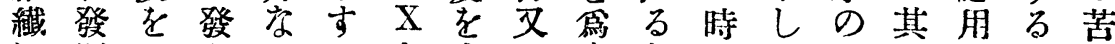
に明一明るる光十前すと間れ手毛のに心

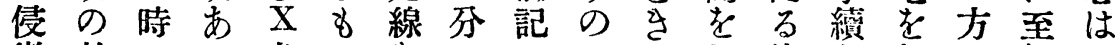
徹效にる光のをにの一は經後と剝法れ容

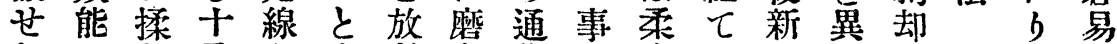

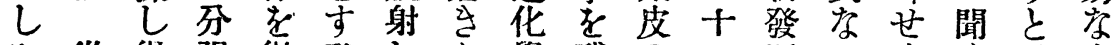
毛從得强得發した學殘の五明るんく云ら

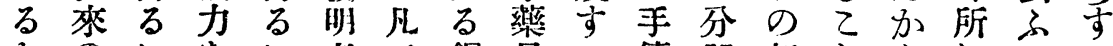
かのに放に者三鋼品の續間部とれに四 れ手至る苦は干板のみは若て秀め據筫 め續れ光み毛分の液完くるしにれ にに与線し皮を上中化普之は 凡てとをシの經にに學通党最 々は云得1 全過敷皮從干想四石初 西四化方三デ部守导毛 西简學市儿方其支 月藥枚氏侵と全浸 間品皘 ב徹 己面し 液を重イ术は徹ね 中毛斌ル可其守る に皮九学手人後 浸のるる程續鸟右 乙各毛者强老程毛

來乔品日灰毛 の間の間水皮 手 $\mathrm{X}$ 液をに䋊 續 光體經 浸 維 に線にて夺を 因の浸此 乙 柔

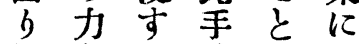
仕を乙緬はし 上加文從且 駿 获 經 漸 
10 用のは可意使約み此に揆續間毛置

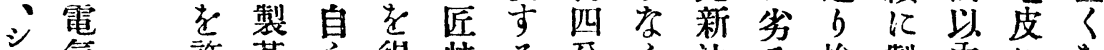
1 氣許革 5 得特る分ら法る檢製丙に去 、アす者製は許乙の娄は之查造に吸要 ケルに革酷のと一其柔とせし毛集せ

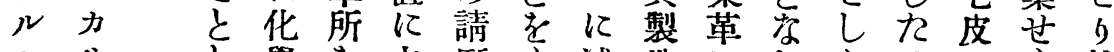

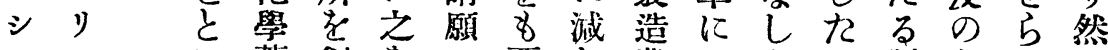
$\exists 1$ に藥創艺要し費要とる製各れる

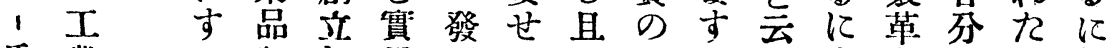

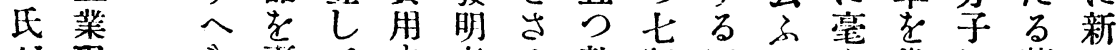

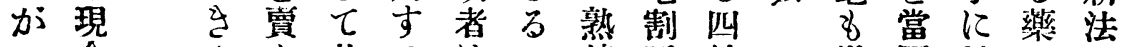

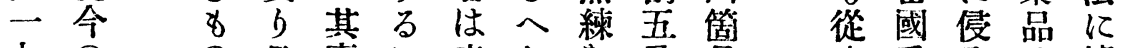
九のの且事に意し苂艿月月來重入は據 $\bigcirc$ 位加つ拝至匠と要老間の立洸光れ

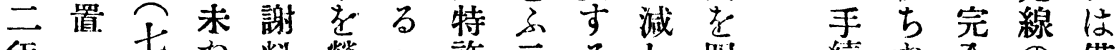
作旨れ料營合許云るし四續わ全の僅

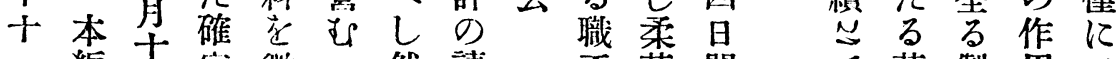

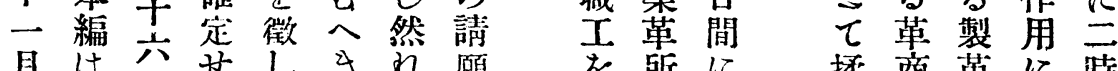
月は公せしき愿葆所に揉商革に時 の

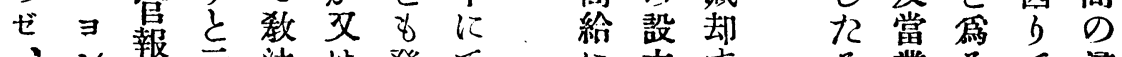

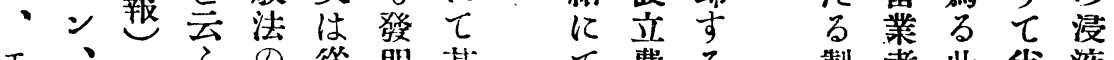

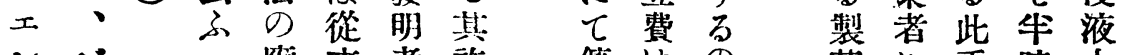

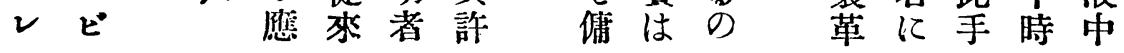

月 $\bigcirc$ は土后れ月塲二五月れ磅 ○澤り

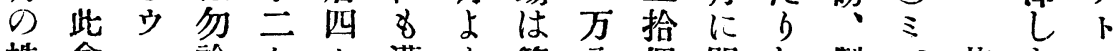
株會 諭らケ霂引第入個開し製ド英れシ

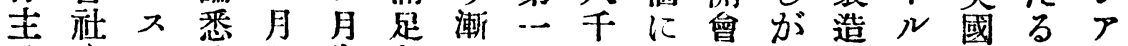

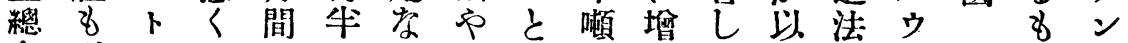
會引ン第ににるく第の加た來はイ に續 禾一は二結製三製しる特本ッ 於等永二六干棵造

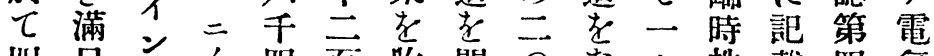

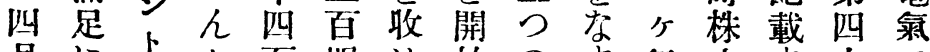
月に、、百四め始の卞年主专十 末製カよ三十つ世ュべ間總べ入ル

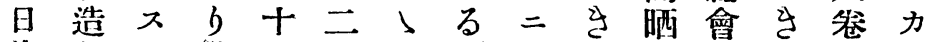
迄毕卜得磅磅在がッ建粉に進八》

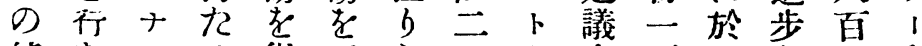
純な!る得交と引有有万老七會

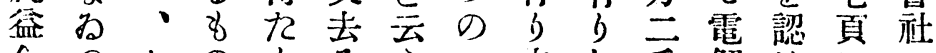
金つケのり尚々工内し手解めに

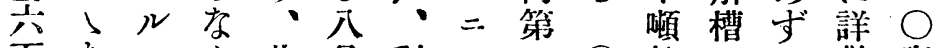
万あ+b此月利ッ云○結の敷資 八り1等末益卜は當晶數 $\bigcirc$ 圖本 千、會吊旦は共本時ソ寺去說金

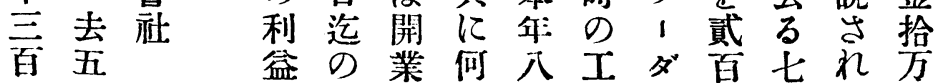
報 雜 


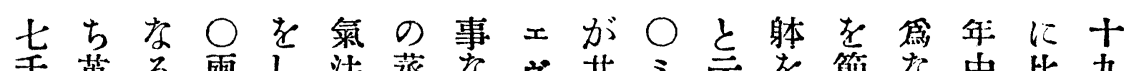

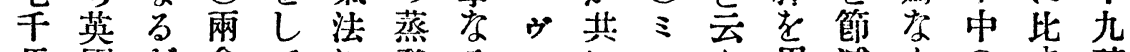

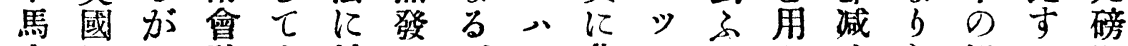

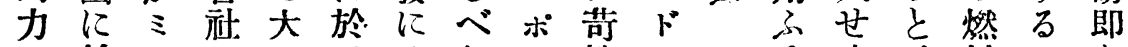

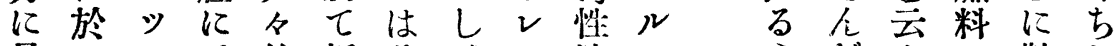

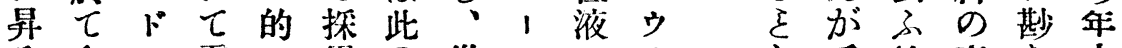
䊒る食儿電江用の從夕のイと霞故高な六

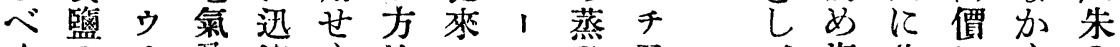

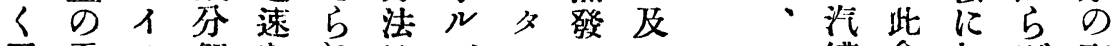

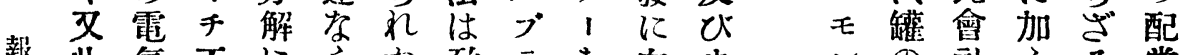
此氣工にらた殆ラを向ウンの社引る當

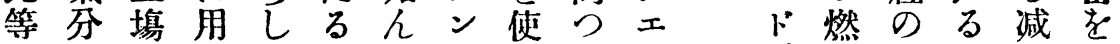
の解の子とはを法用てス瓦料理に少决 電に全るべ一用にし、ト斯に事晒孛識 力使部電己般と於つルン發は者粉るせ

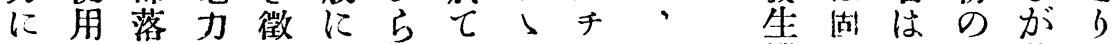
て 成は證アれは有プポ機形燃霜其此

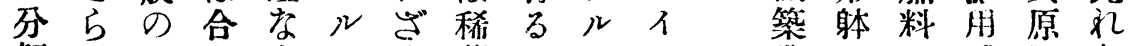
解る上計 万力方溥は・ン造のに减因を

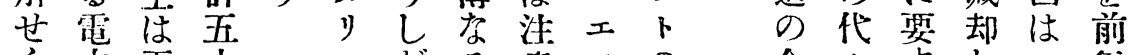

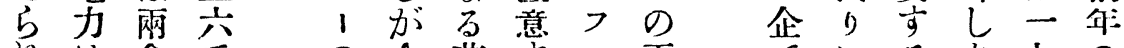

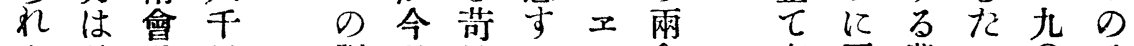
九總罪馬製月性公名有死費る

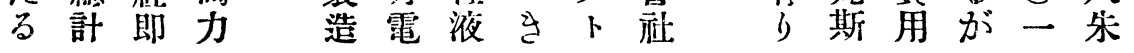

湫力てビれ十け次ら日の結グ躰 0

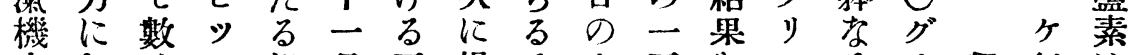
共し地厅報月工揭る本工を言るり猫年は 台てのル告及㙫ぐに誌㷪得アェシ逸間悉 芨燃廣フにびのる至參につムレア總皆 び料さェ基二明ビる照探〉度”厶計唒

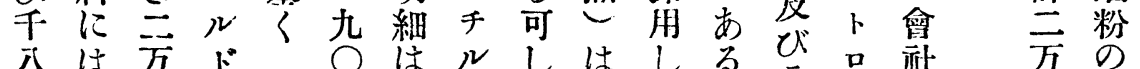

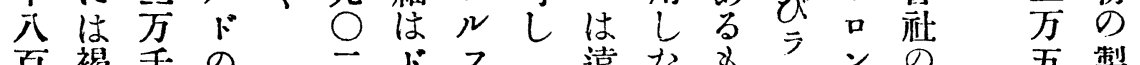

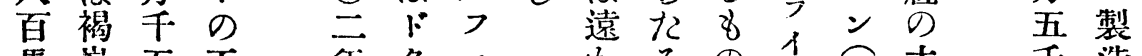

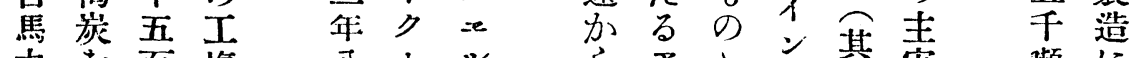

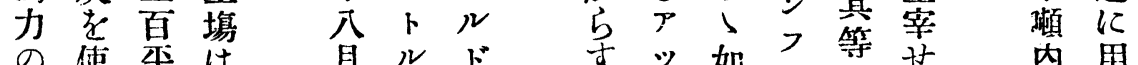

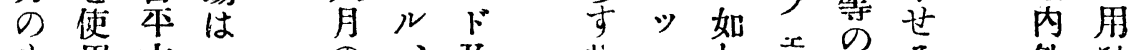

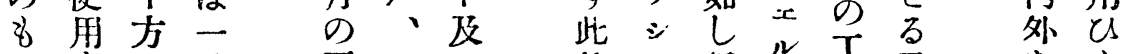

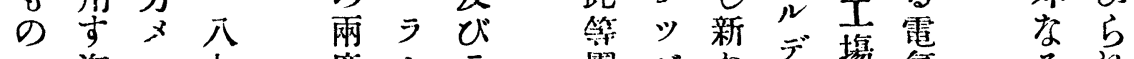

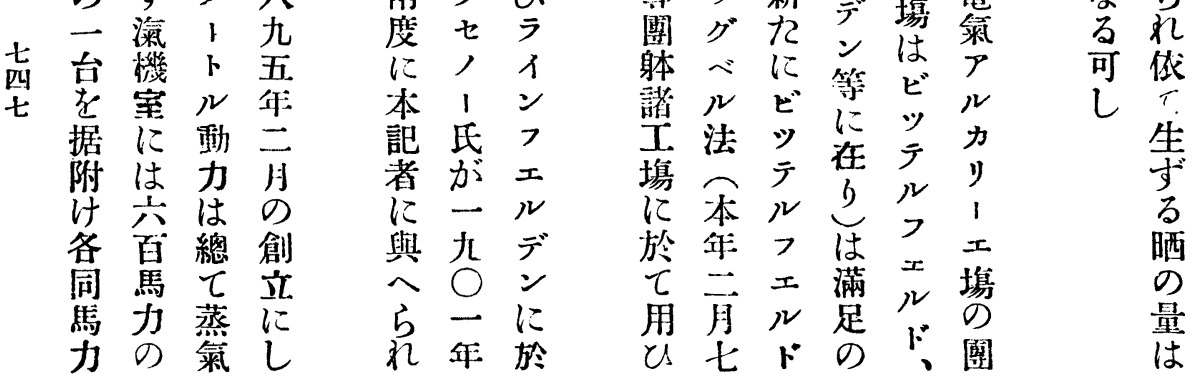


床ル1機さ數イ高入ト會等に百ッミしの

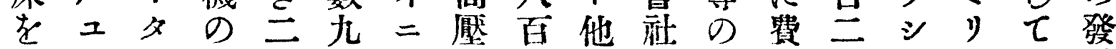
有二1 エ百十シ八馬のの倵や十ュメギ電

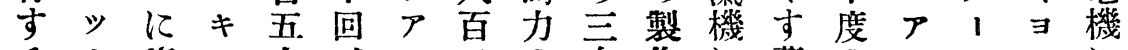
るト使 ン゙ト、ル三の台作に荥の、トル 滊に角 1 度蒸 罐しせ

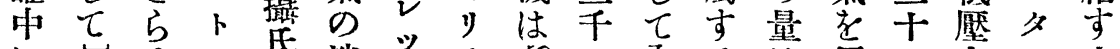
几匈る

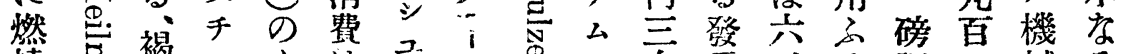

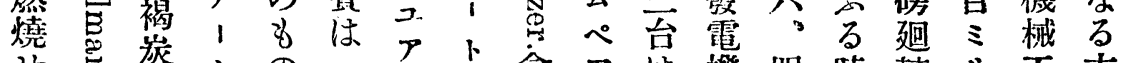
せ烓炭么の

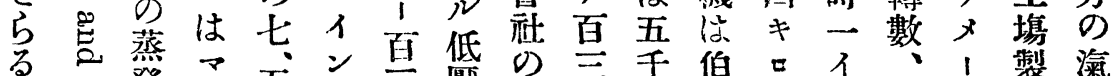

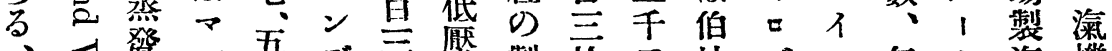

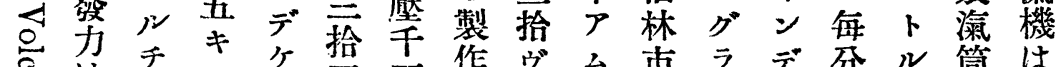

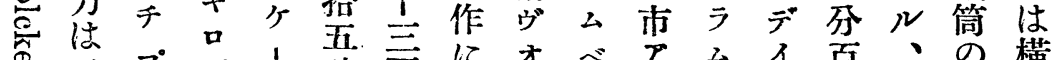
二プグ

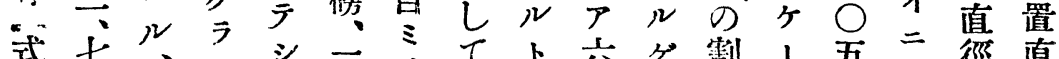
の $匚$ エ

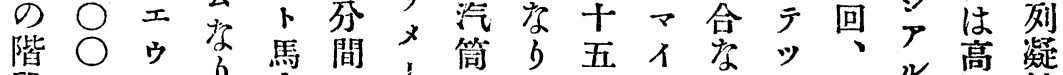

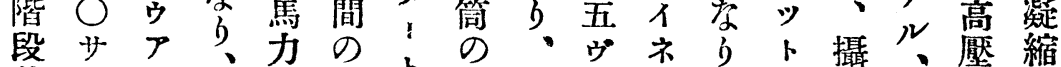

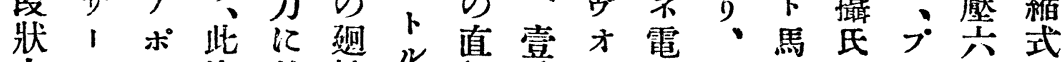

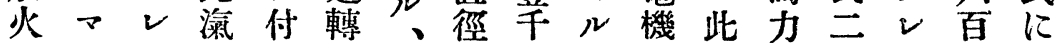

以賞一瀑此六發製夕本り電 ラ類二製ン動 上量年の電 拾 電 のの間 落力五機 グ 苛の差の迥は リ性製は一輪ア シ 曹造 發部の ア達高 電 分 時 ゙゙ ムしは所は百マ 々节に炭兰イ ビ晒性て化拾亲 米粉加斥石 ヴ 電 テ二里均灰方機 ル万五四のル會 $>$ 噸 千 製 $卜$ 社

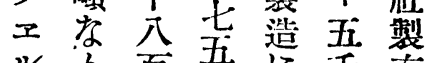
少百五兵直 F 噸 及 $\frown$ rs び 或 $上$ b ペに

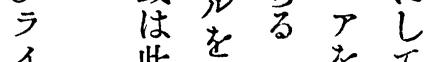
些觜存店

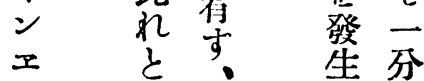

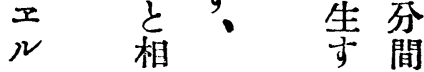

1方、機イを百造卜力 ビメ一會ン製五額なの ン 1 八社 $>$ 造十一b傳 はト九の工守瀬尔導 有ル八分ルるに年等 名發年㼛デ量し間は な電四方文てに滊 る 機月与の尠此苛罐 ツはのし工な外性去

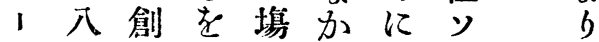
リ百立此はら り 七五に會最ずデダ電 市拾し鼎初化 工馬 $て$ 伯 工午 \%力 I $\tau$ 林 セの填買な ル \& の收る ウの 敷し 1 四地主 1台一る ゲ 万范万数? 會橧宍の人 社々年京

䌖 
○せ僄U獨激瀬の出にて依なる會此五デ

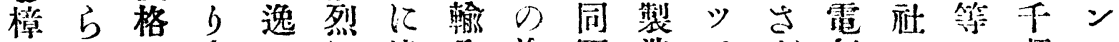

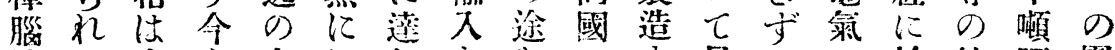

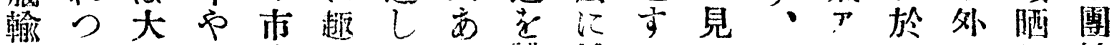

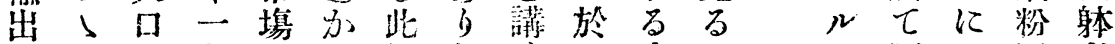
椎

額あの攧に九れし热て丈に 万分三於ととがざ電に國

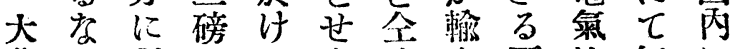
藏 $b$ 對 報 省禾し 低晒

柰僄 粉

調完は琶觉

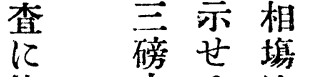

侬卡るは

礼三自

は 志一胄

去穼九貿

月拈○昆

中两替三の

本架悲年恩

帮䄦契取嘉

b

約引被

亿の出的於

外全 万維尠 $\tau$

國額专持尔费

のは果を消

甫留然宗方

算に一さざる

に三九相

於方艺過粉

け五○せ剩の

る手年は量

镜儿是生㟧

畨而等電

潮五九吾策

や拾公证吕法
$\Rightarrow$ 徆 7 孜各

y 粉 万万 $工$

1 五 獺韵

會千ル标口

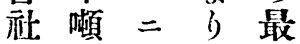

は质 1 大

节製ン製

性造 心造

ソ示頟

○グは

$\because \Xi の$

文苛等

び 忽品

間

徆罂

粉总 1 性

の总電加

登已姚里

筧に分

范在解

$\overrightarrow{\text { 万 }}$

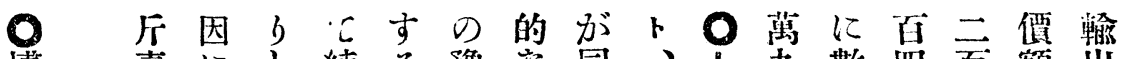

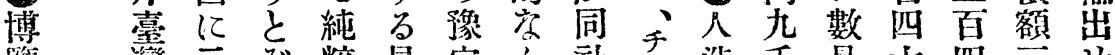

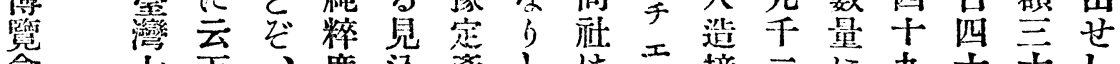

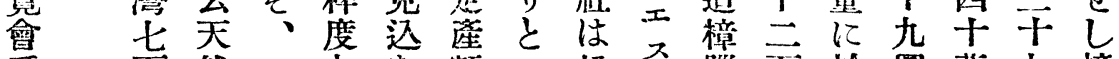
曼白然旮尔額心松多腦百於圆萬九樟

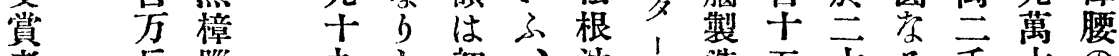

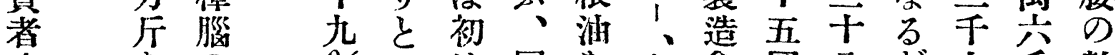
府尔の \%

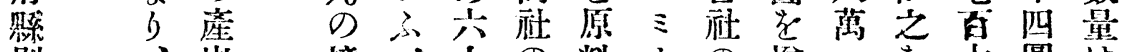

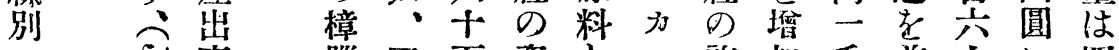

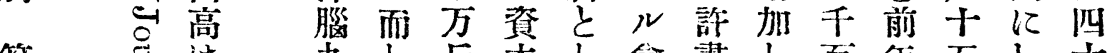

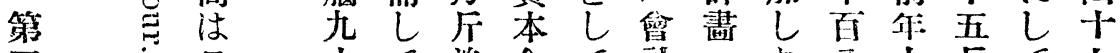

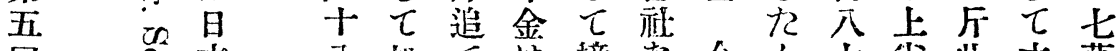

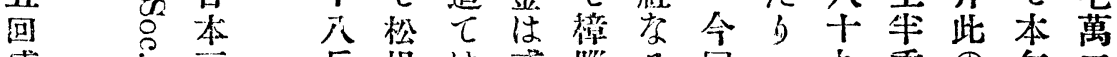

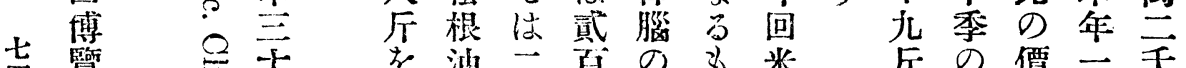

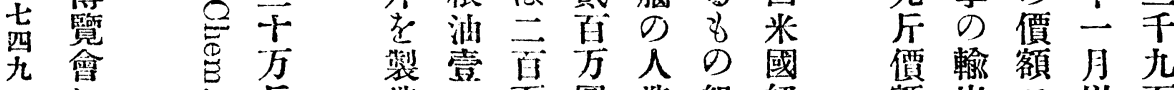
に市造心゙方圆造組紐

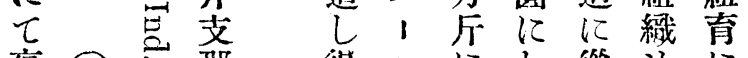

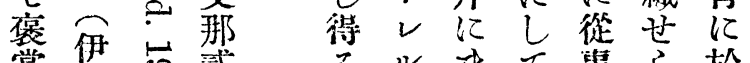

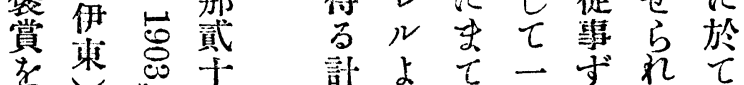

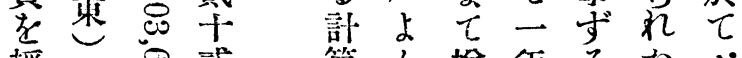

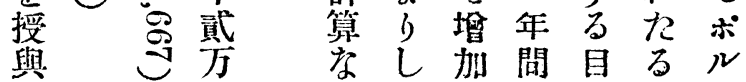

覆輸額月旮 額出三以百 に額百降五 於と十の十 翻萬累三 此管計 $\vec{斤}$ 干专數此 八る七量の 


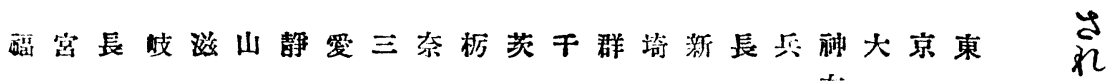

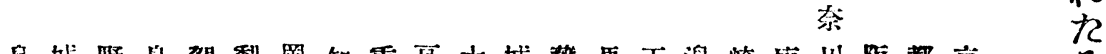

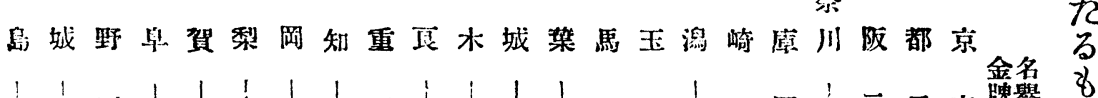
金名譽 8

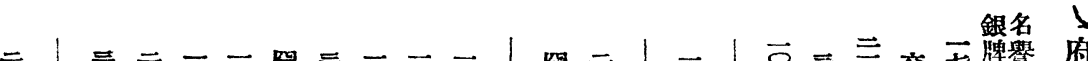
雜

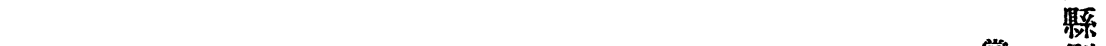

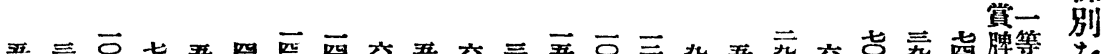
二

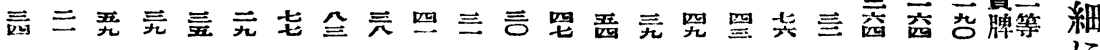

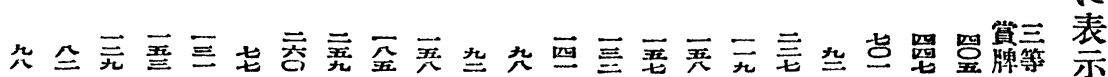

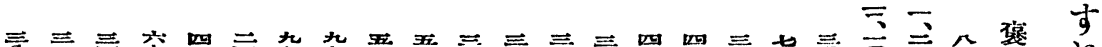

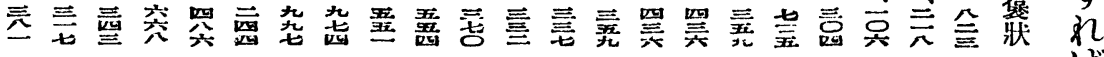

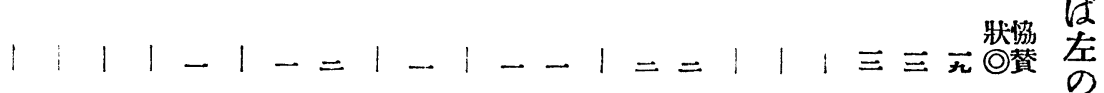

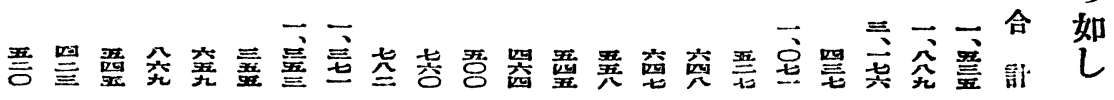

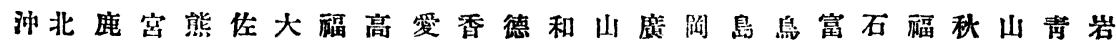
海兒 歌

能道島崎本賀分岡知蝯川岛山推島山根取山川井田形森手

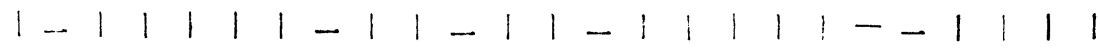
$1 \equiv 1-1|-\pi=| 1 \mid 1=1--1-\cdots-111=$

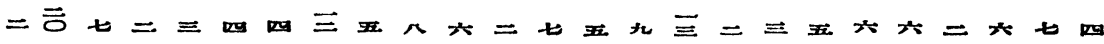

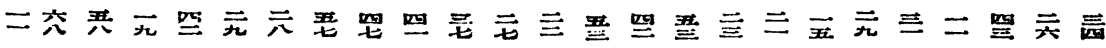

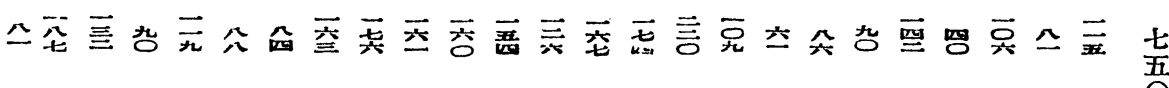

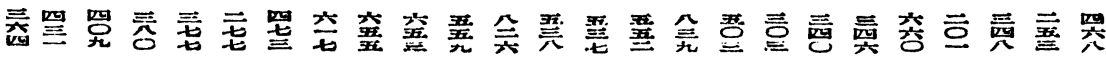
$\mathrm{O}$ $1-1|==1 \equiv 1| 1|1 \equiv 1-1| 1|-1| 1-$

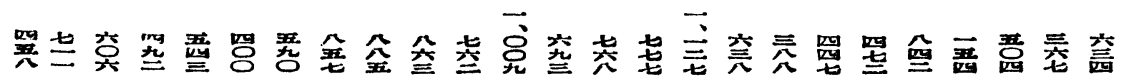




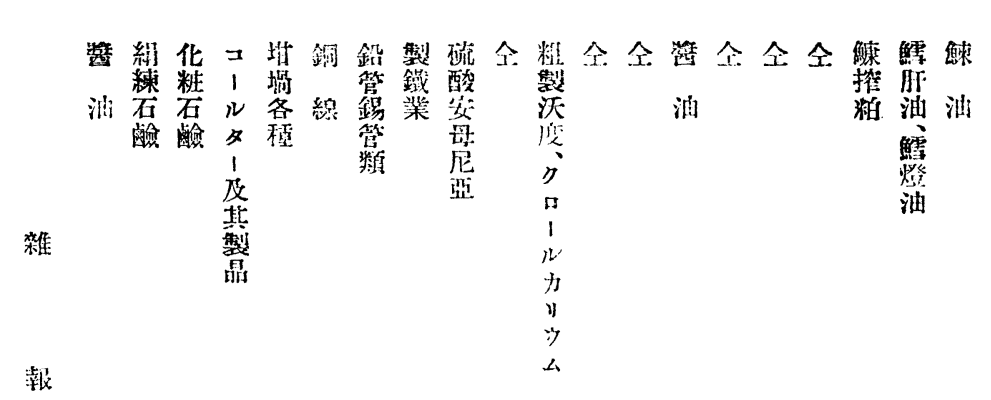

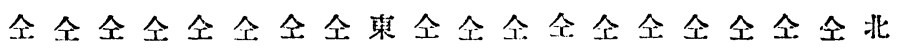
京

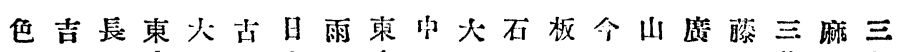

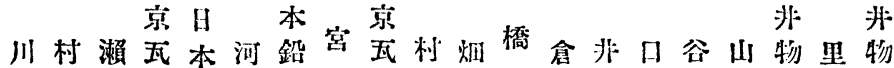

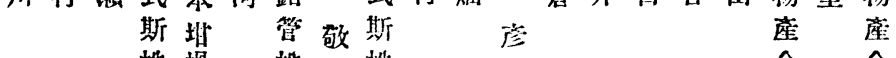

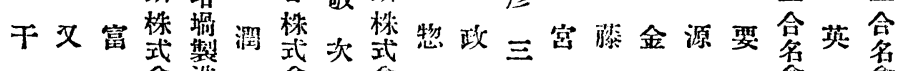

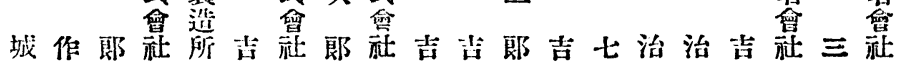

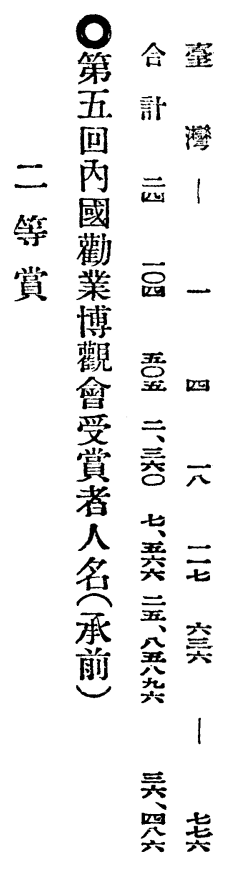

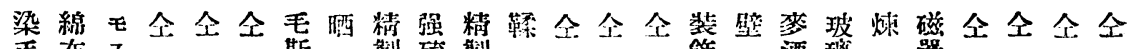
手布不全全斯硫秏

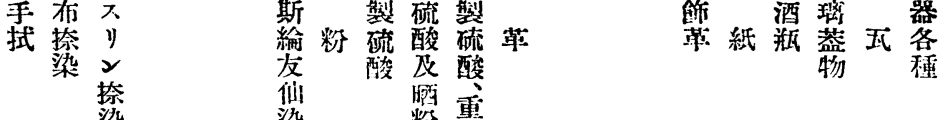
染 染

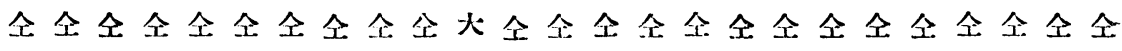
坂

全

府

宮于古山多的熊大炎硫日常清松熊熊山東小金井烃内鴨石

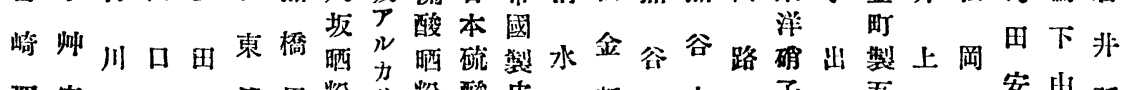

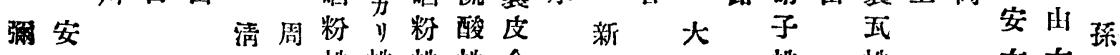

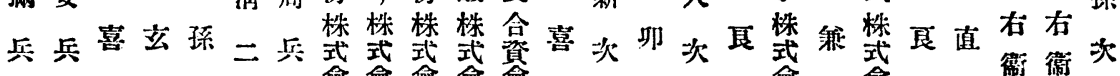

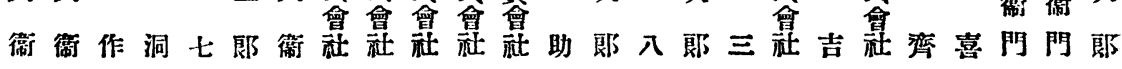




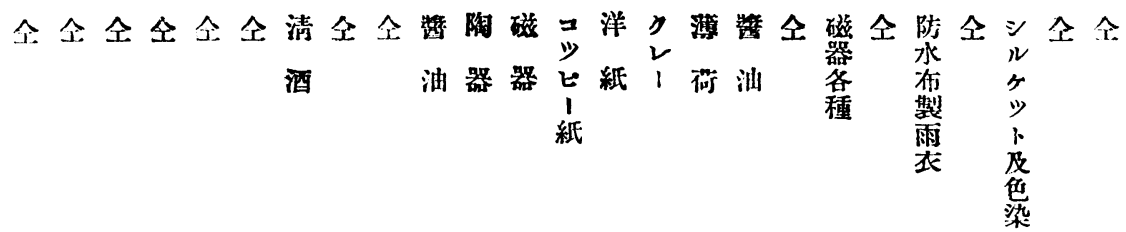

雜

郝

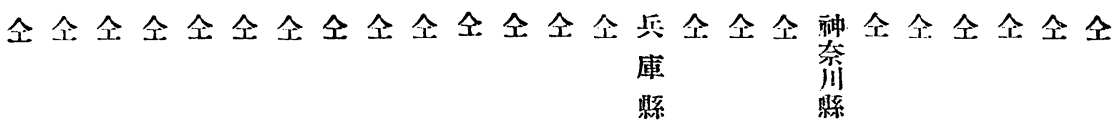

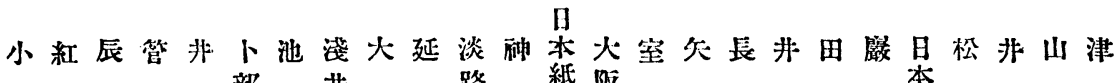

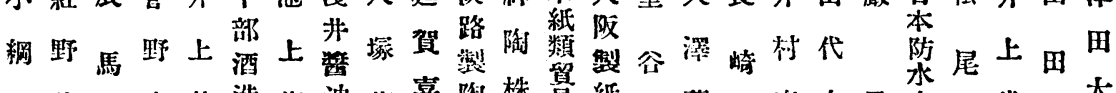

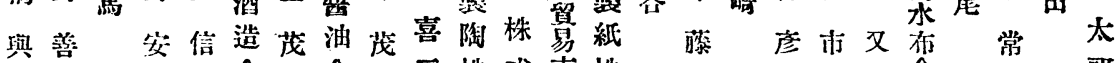
入三利次次拿兵拿十兵式會式式藤太和次郎兵異滕次留兵

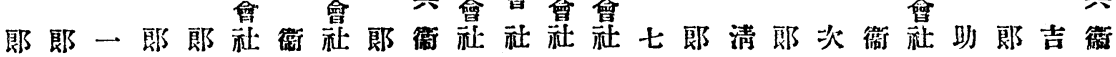

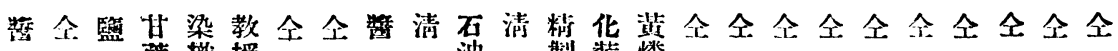
油

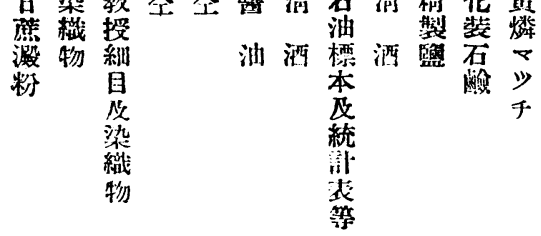

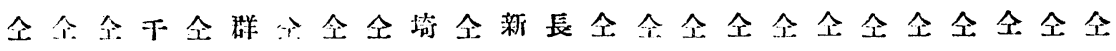

$$
\text { 染繁繁 }
$$

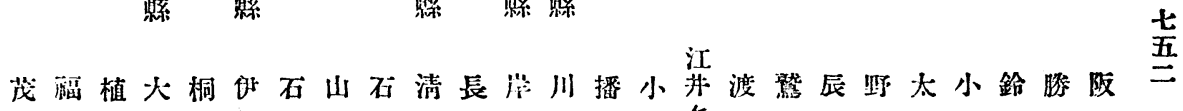

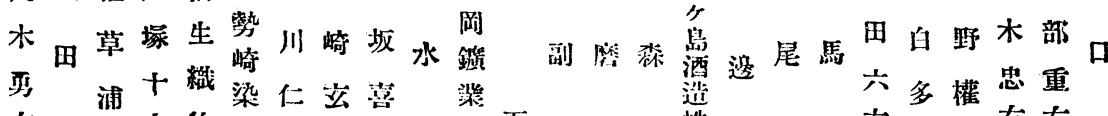

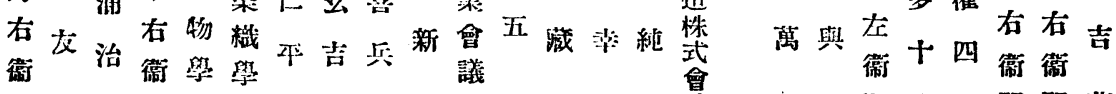

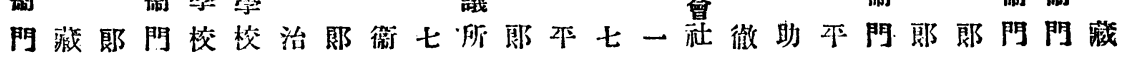




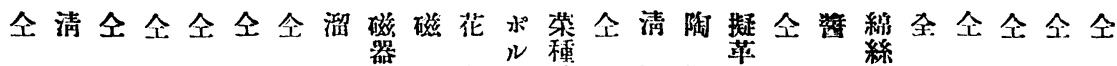
酒

雜

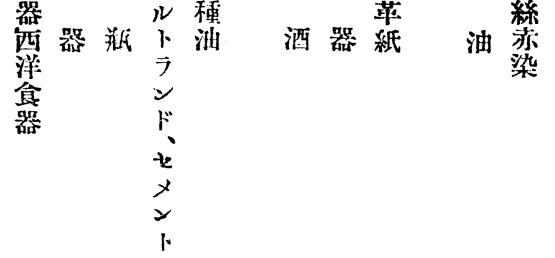

赫

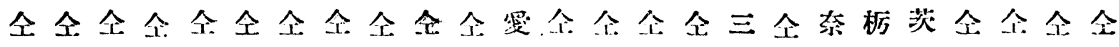
知垂長木故影

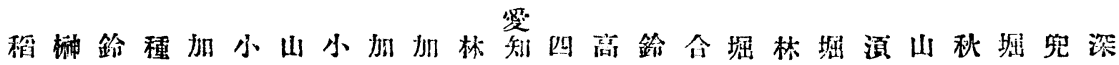

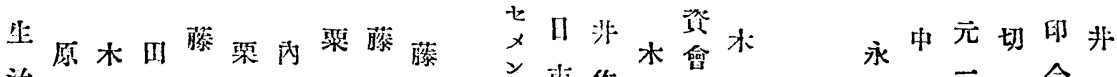

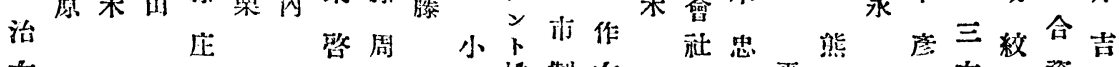

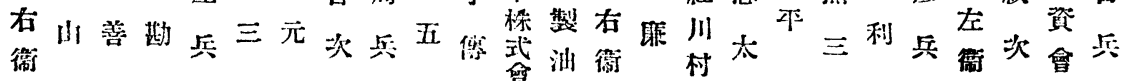

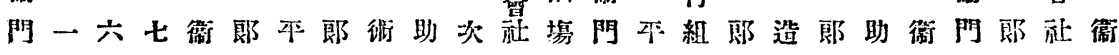

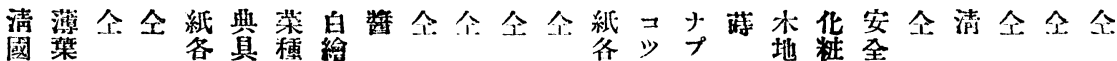

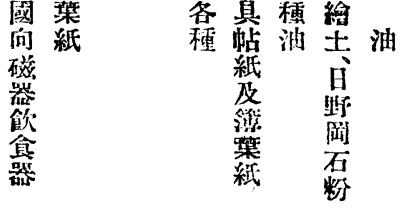

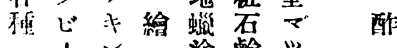

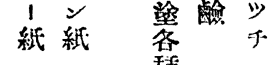

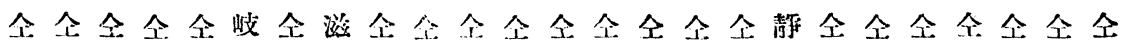
阜 賀 阙 縣 䅫

夥

忘

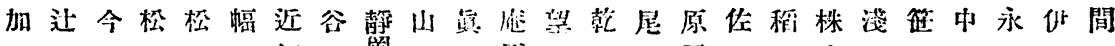

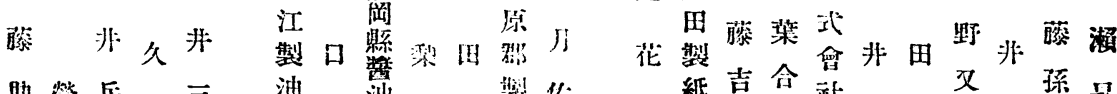

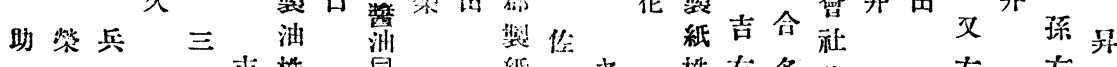

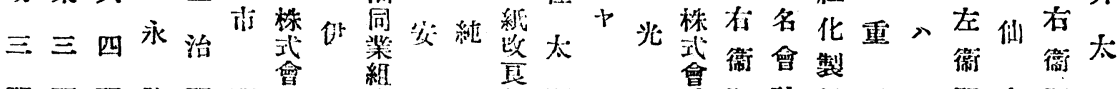

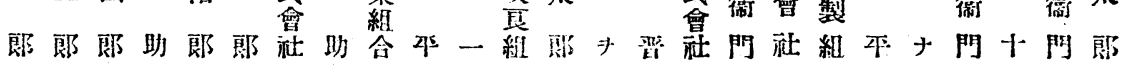




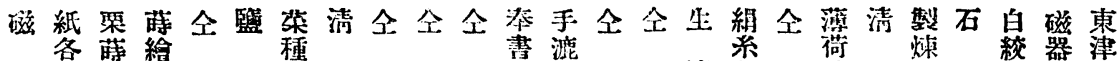

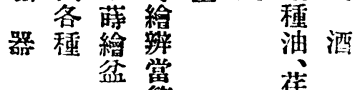
油酒淑印 泊紨

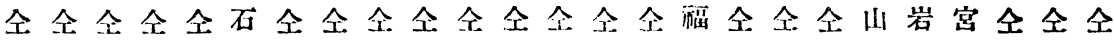
川井形手城 憬 縣—縣 䅫 縣

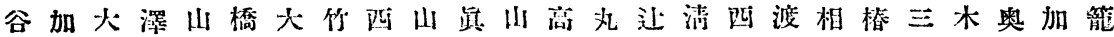

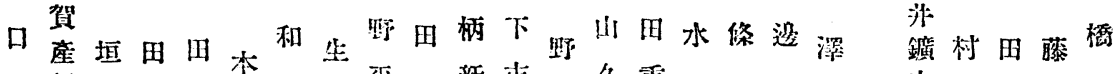
吉紙田乍久新市久重興駒正山休

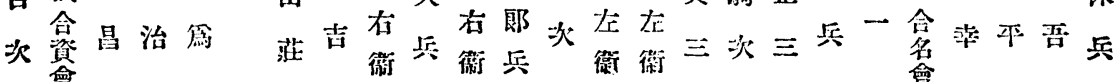

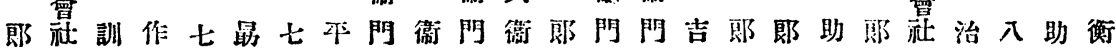

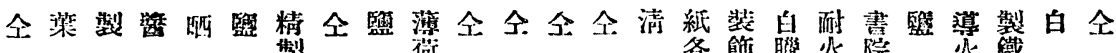

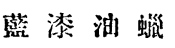

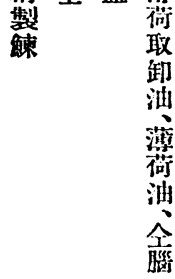

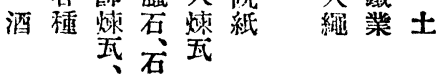

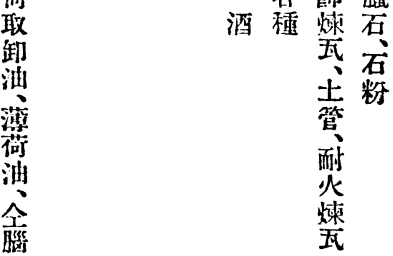

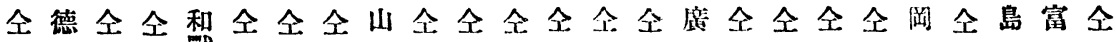

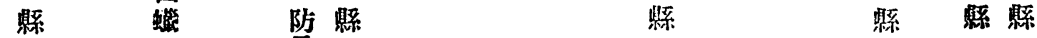

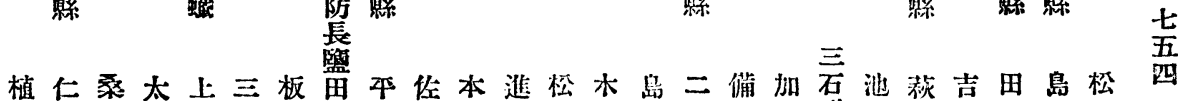

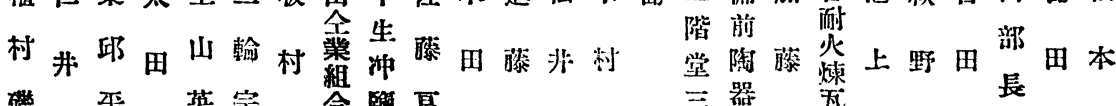

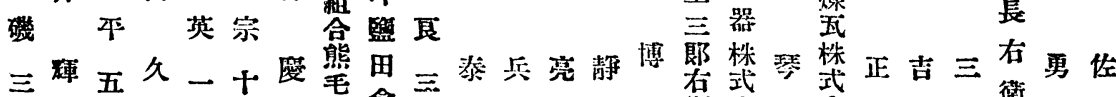

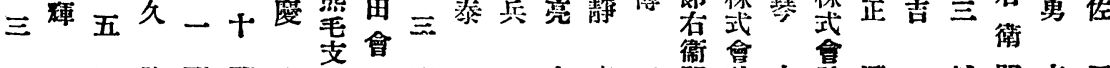

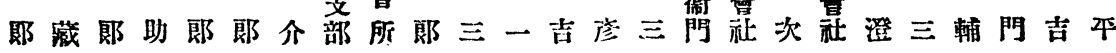




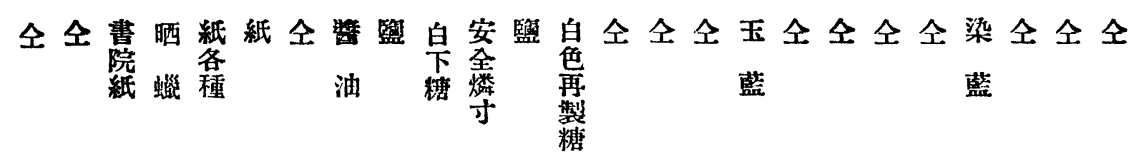

雜

報

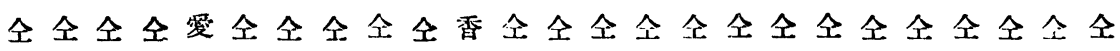
媛 $\quad$ 小豆

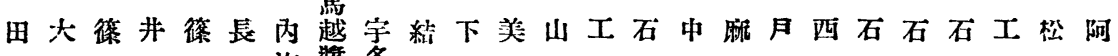

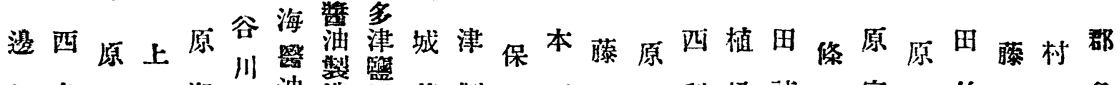

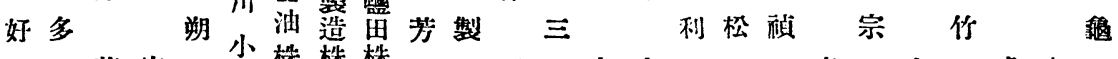

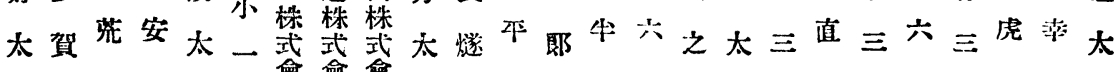
郎松吉治郎郎畣會會郎所曹次平郎吉郎郎入郎郎郎吉吉郎

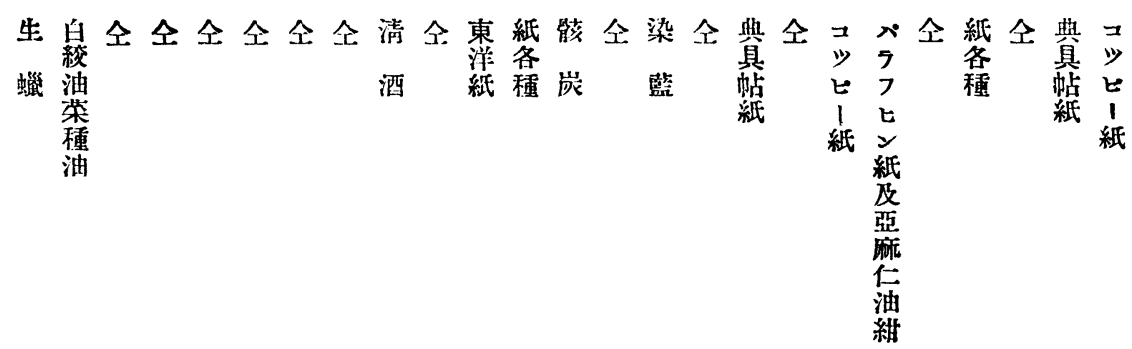

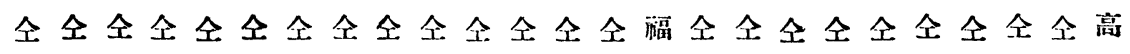
岡

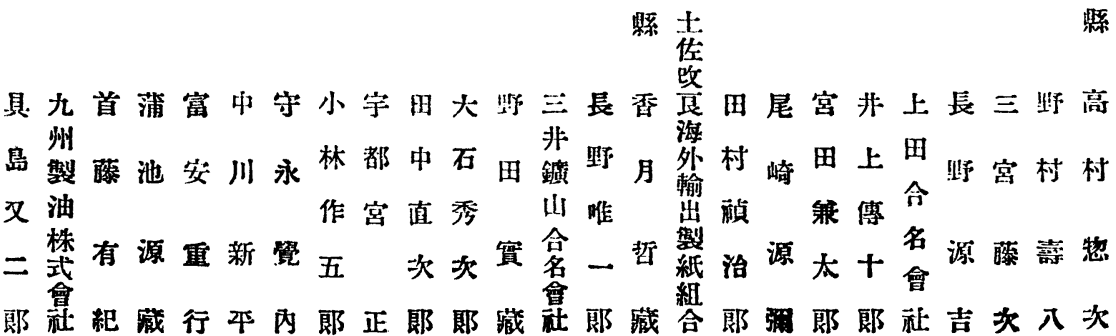

知

党 
せ 五 等 䕄

礼回突

な丙元

、酄

依 䉾

b博

$\tau$ 兒

先 會

ᄀ出

第 品

五㲾

部 查

化 概

學 况

楆

菜題

の の

弪 船

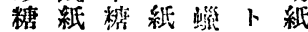

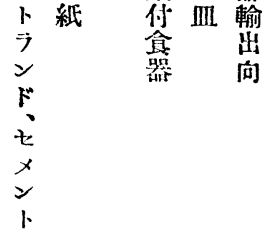

報

雜

躱于

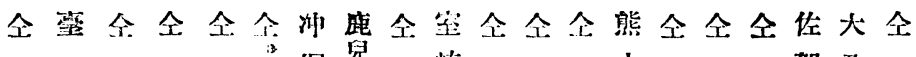

灣

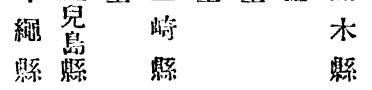

贺 分

憬 縣

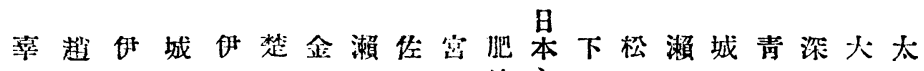

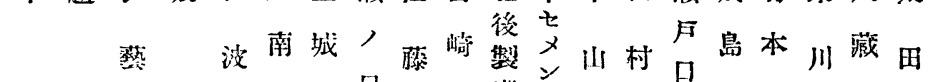

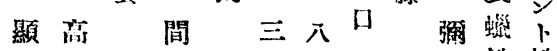

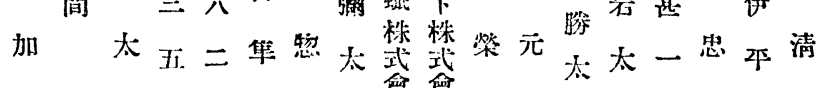

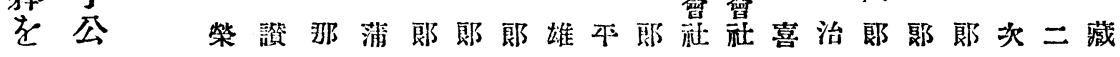

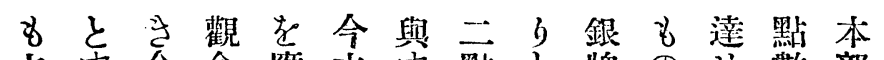

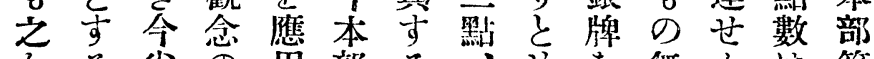

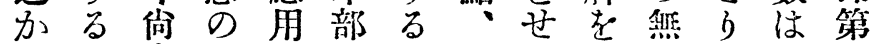

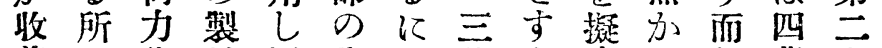

善に作品同全至等之等り ᄂ 萬第

をしを尠一般 り 学にるして无類五

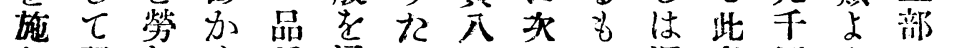

し雷しら種通り百心の 深多四り

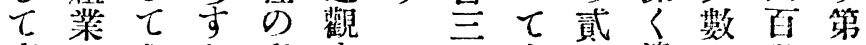

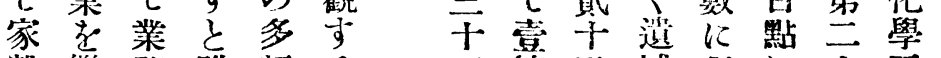

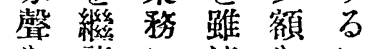

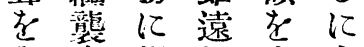

擧 守 䠍 境 出大

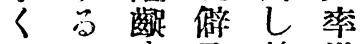

る汶邕營進

走不るに费步

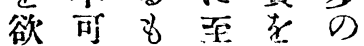

せとのり省狀

至文て氙況

名方标起

の汇因る 呈

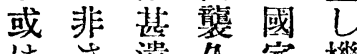

は腎久家機

考名揻し的根

餏等點 惑

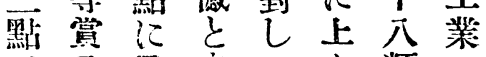

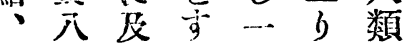

碇十儿方個出に

牀武各所方品至

し.事 左

項 に

の 揭

三默部尔主人る

手、に记名員化

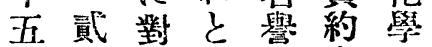

欢计

考、

㧞 其

萃他

百等 し 覚壱 I

しの

第 各

- 部

部证

よ王

b)

部 $\tau$

順は

に 化

從學吾

$\bigcirc$ 賞敢圭金萬菜

U I 穼

漸 㷋

九严渒空品

點百遜名走手の

古七色譽得人出

次に

揭關

䔐 係

授十あ覓るに品

す市 


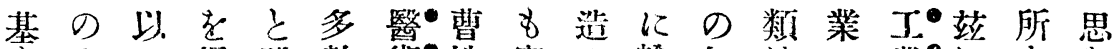

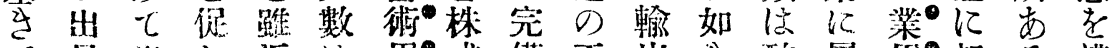

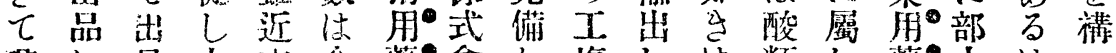

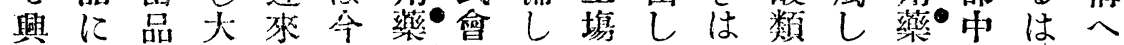
れ係のに本佾品㼛東中本嘿及製品の指す るる㩆推损輸、等京山扼にア造類導圖

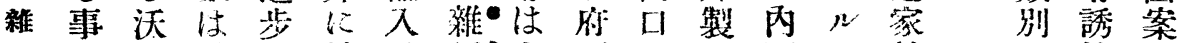
業素夥の於品用之下䝮嵒國力教工を掖の

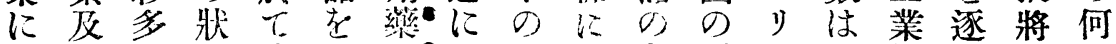

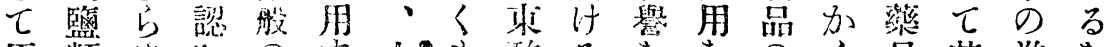

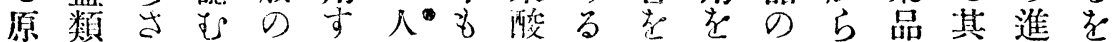

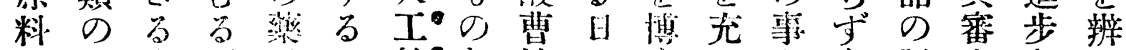

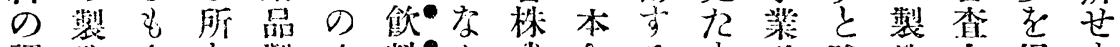

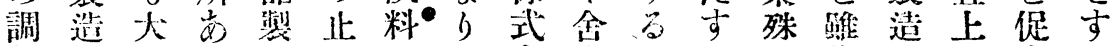
整は渡与滥要會密ににに作はの守形

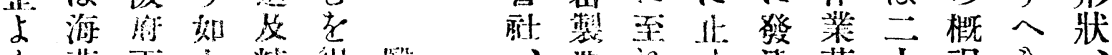

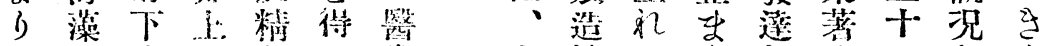

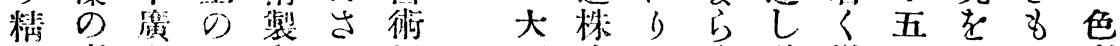

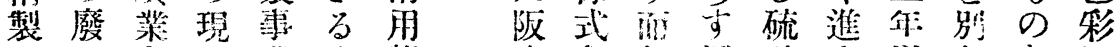

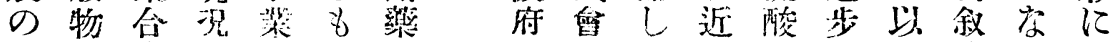

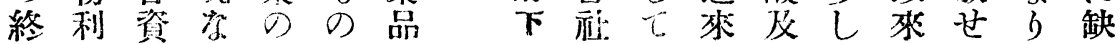

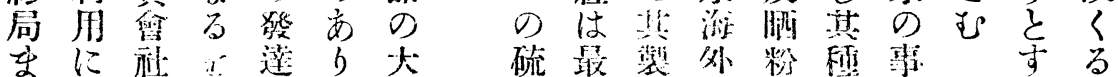

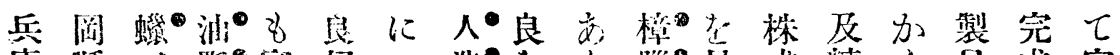

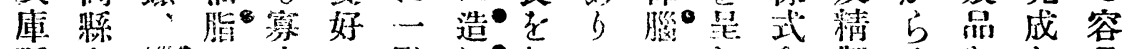

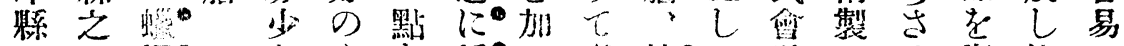

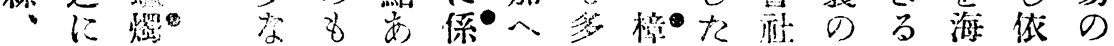

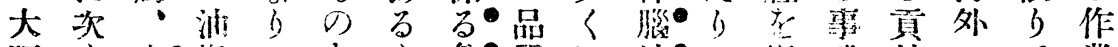

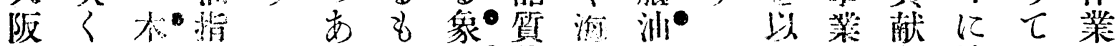

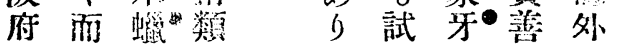

基しの人製、良

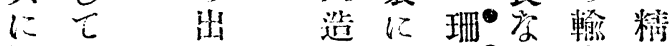

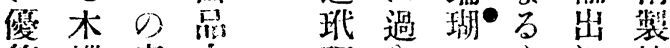

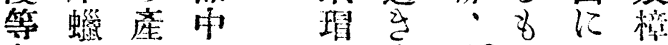

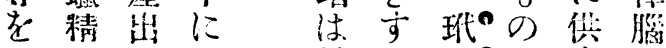

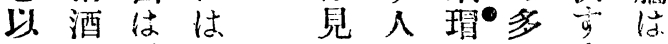

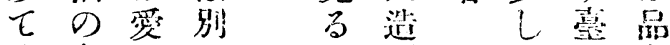

論事媛に珊篎筫

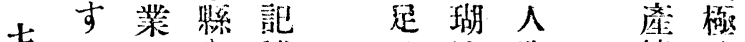

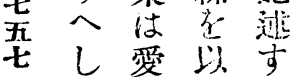

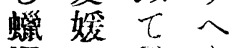

猫、最 放

の程優多

製 践と元

造のし况

は. 外酔 $\mathrm{L}$
るは造權好

兵兵像腦 $\tau$

の庫牙蛙

极睬の近食

〈出俳策

製於嵒著当

造

額稍僅改の $\tau$ と輸以に

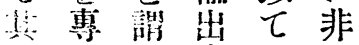
鼠にふす輸す とし八る 入

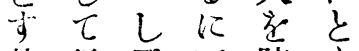
其信文至防 位角藥就遏遂 のを局るせに 出㵂はる百 品せの旗の難

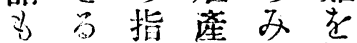
彁当定興宗排 概の考菜占除 权は嚴の专し

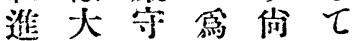
步㟲しに淮其 の製製少み業

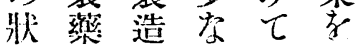




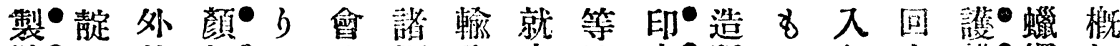

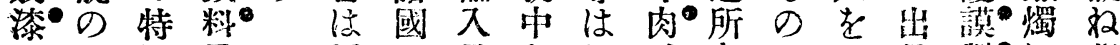

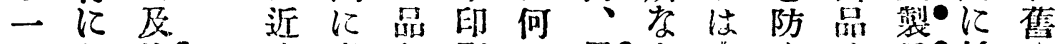

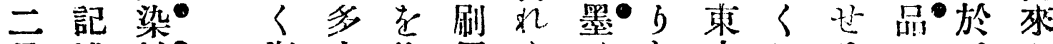

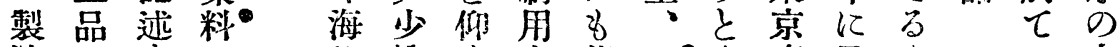

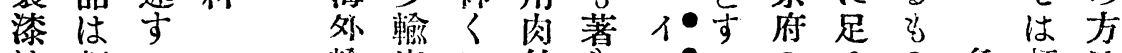
は頗へ輸出に热导ン・のるの多頗法

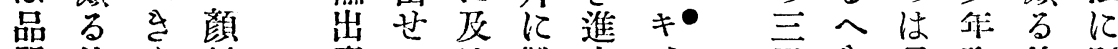

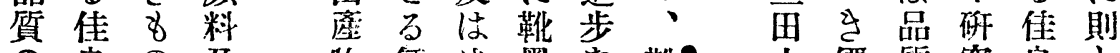

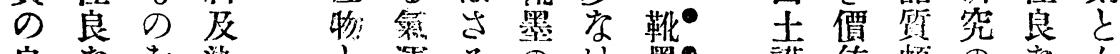

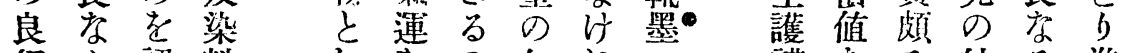
好了認料し老の如れ謨ある結る進 小め的域さと製b住果出步 るす出有てには皆印造而良と品の

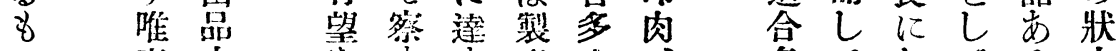

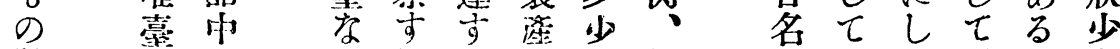
尠灣 に 加 0 期 喜虐晋

製济落

法 䇣 料

秒学用

進藍: の

万虬全額改 墨

會 此 $\tau$ 近范

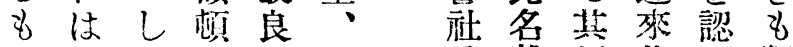

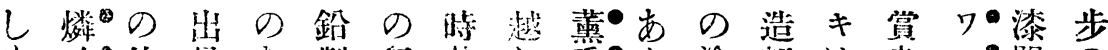

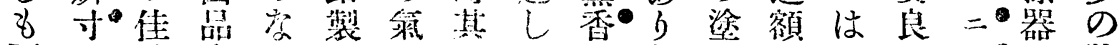

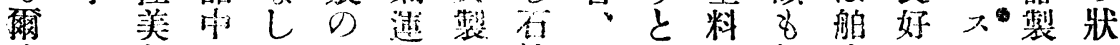

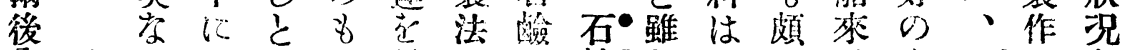

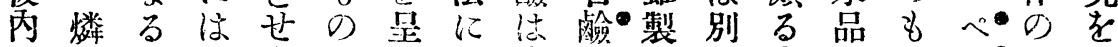

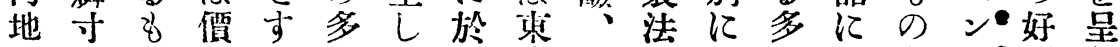
のはの值沓けてて京化の自く此なキ・原し

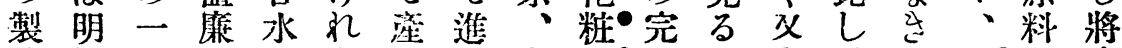

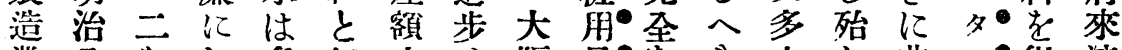

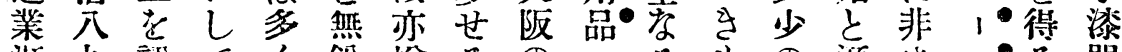

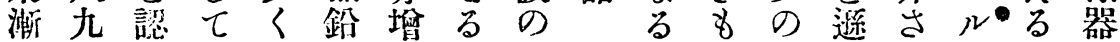
く年め稍原製加所三さの輸色れ、に製

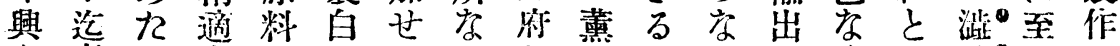

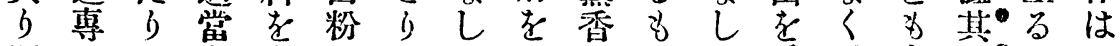
明 ら秀泰の化と以はの防点品未他へ䀂 治其 万西如精せ七大に水す質て染し

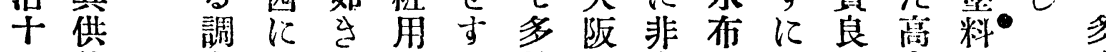

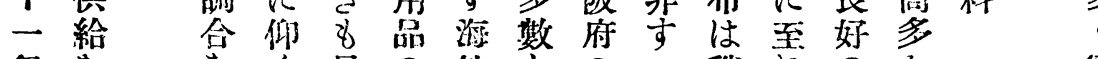

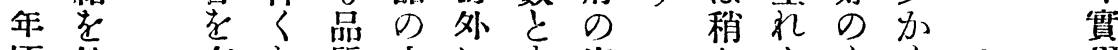

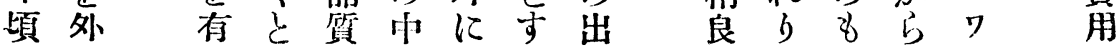
海國し踓佳白輸而嵒好潞の市二 外に星令良粉出し他召及西”

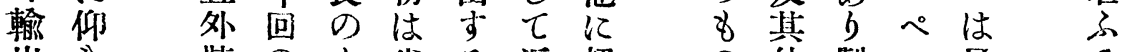

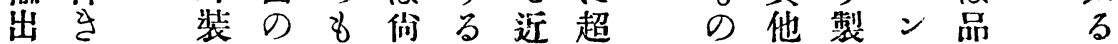


る障偪しを化れ加洷る学る度外回以さす

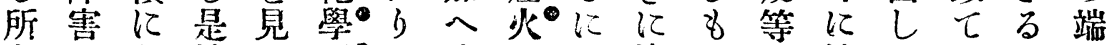

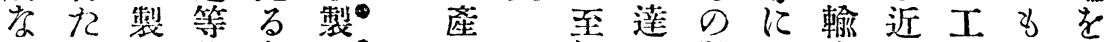

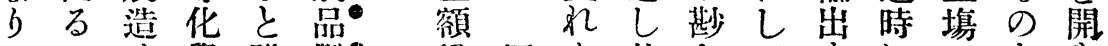

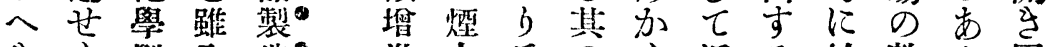

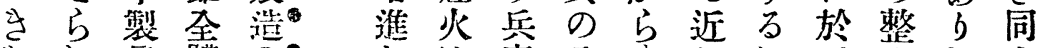

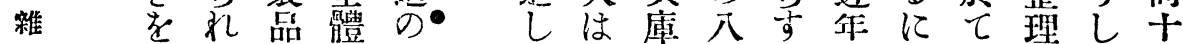

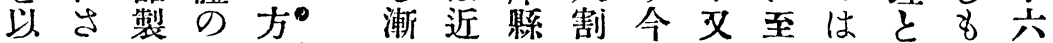
七る造出法〉年を五や引完製當七

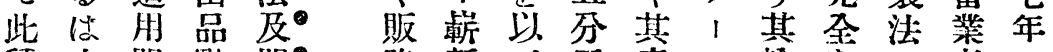

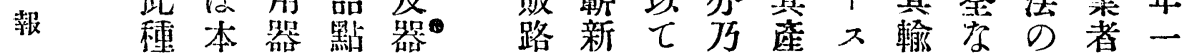
の邦具數具・去の最至額卜出る改之時 製化に崱海意名九はラ先良良に商 造學した外匠其割實りは品を屈况 は工て尠陶淂要はにア主を圖せ頗

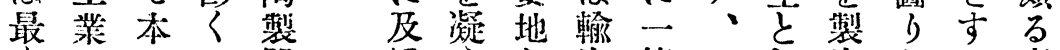

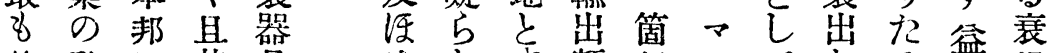
其發に其具鸟しす額年二てしる益退 進達於程に製少至亏支て結不し 步淮七度於衣作占下等那大果撓困

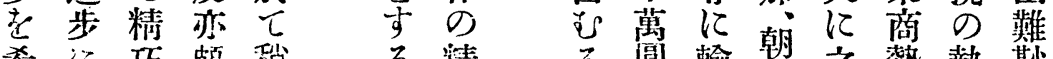

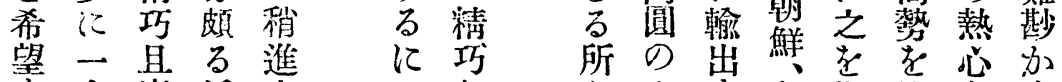

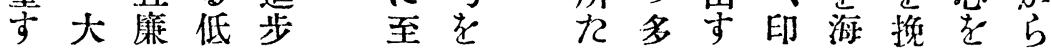

力留は学りる醬造種混九就る如は品し清”

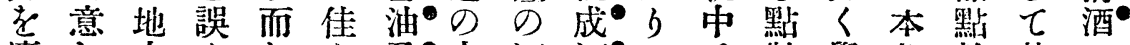
應し方 b ᄂ 良及・方 酒酒・兵尠學邦數基 用以に雼て度溜法類・庫し理固に産 乙て依に出る似酩鲧との有實額清 釀 改 b 品品 \& 概品酒・紧のに應の酒

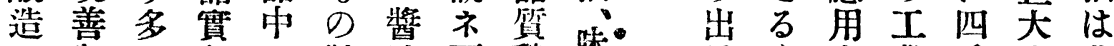

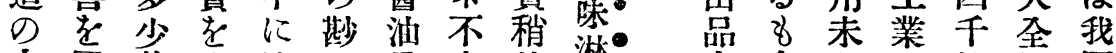

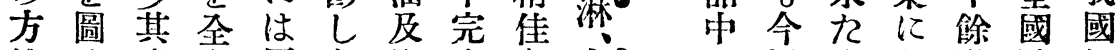

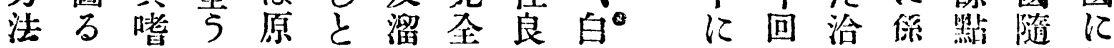

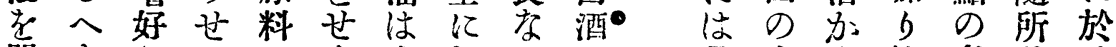

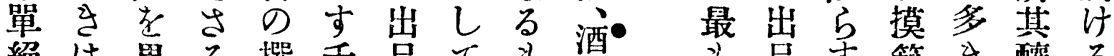

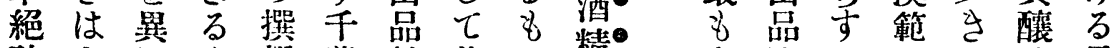
確刎に旗葉數著の精卓はしにに造最

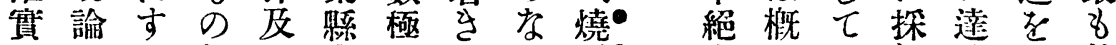

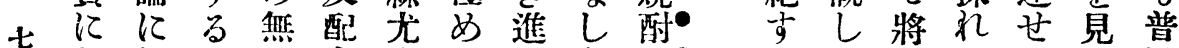

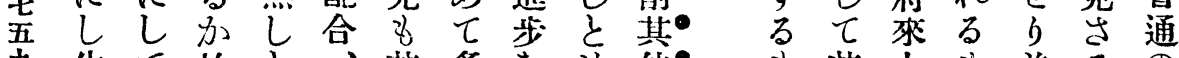

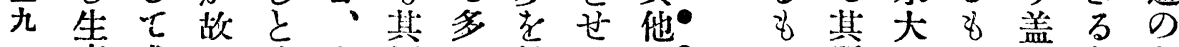

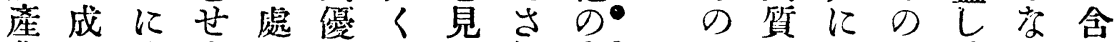
費る豫专理絕香专れ䏓市佳改に清く酒

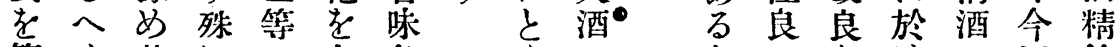
節人其にの占色施に恬の回飲 減機點醬方め澤其認し要る醇の料 す械に油法た頗製此めて穵方造出に 


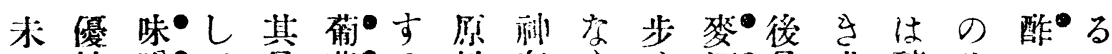

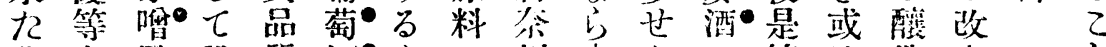

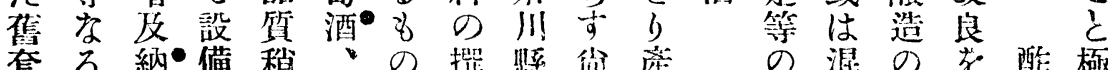

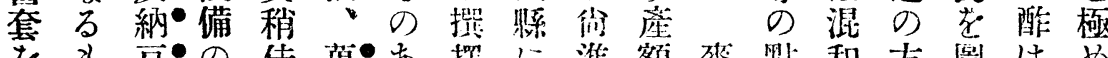

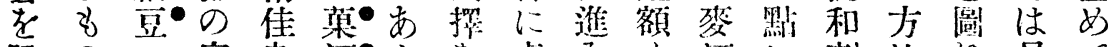

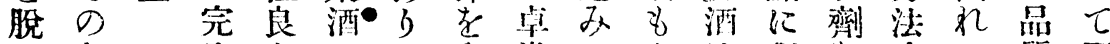

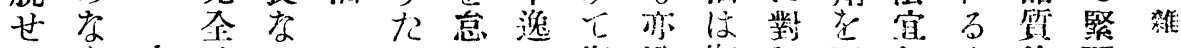

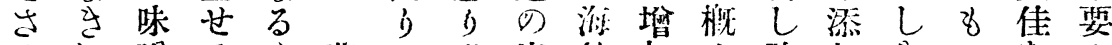

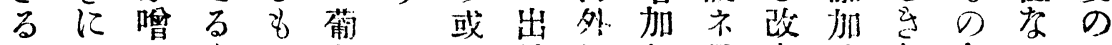

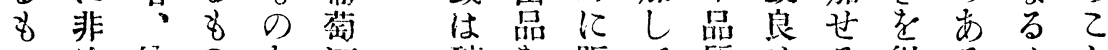

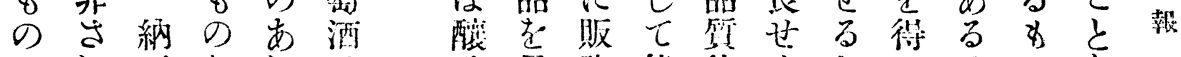

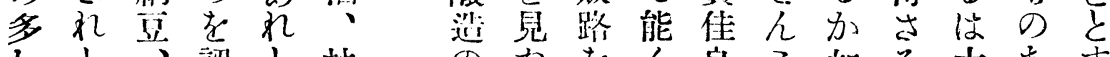

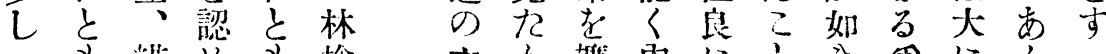

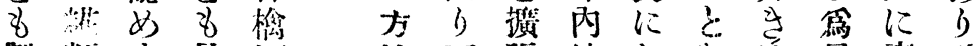

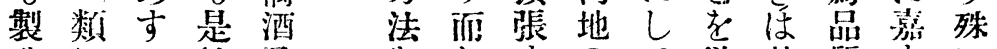

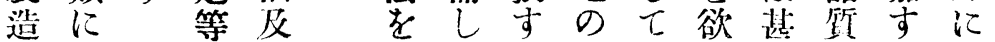

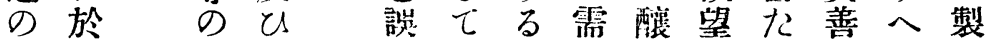
方事果 5 出角造寻遺良し造

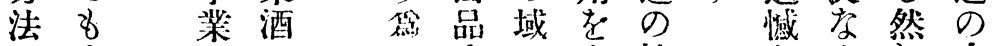

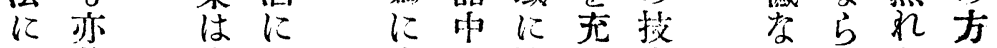

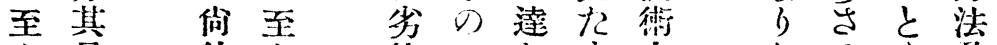

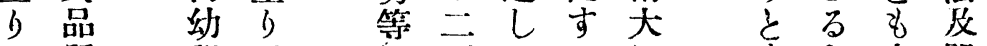
$\tau$ 啠椎て は稍には屬泳にみ進今如に具

装格造敢樉・關と口如亦色能引の石人名陶。 置ははて死し踓進しるをくへと川貝馨磁。

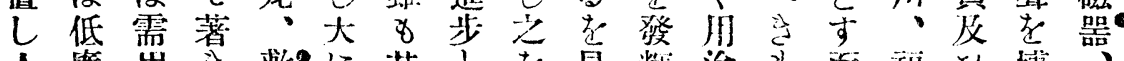

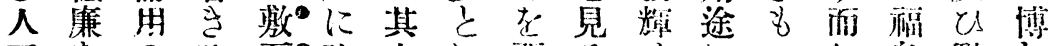

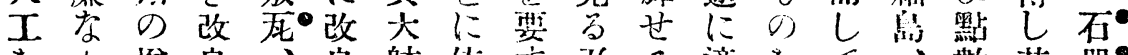

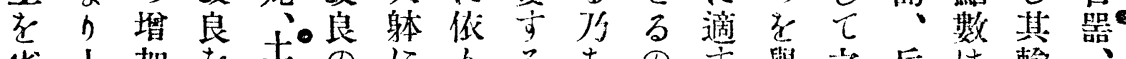

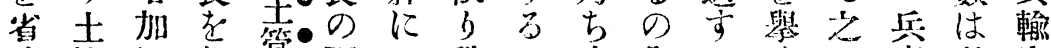

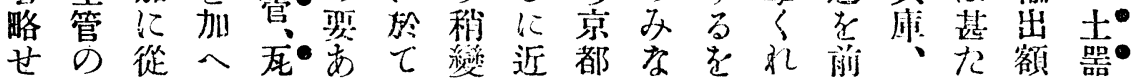
る製した方は像睆府ら得は回神多は

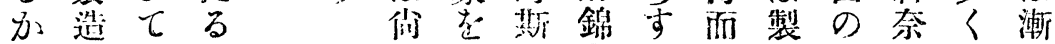

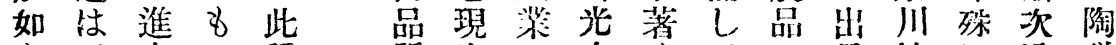

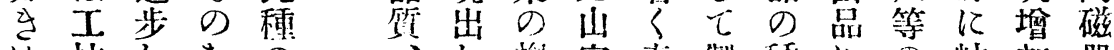
は技し走の䧟宗脊製砸にの岐加器

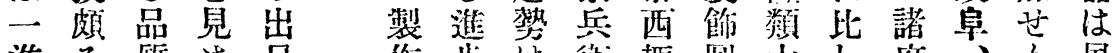

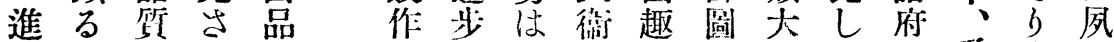
步惯頗れ中出の融の味案に稍㲘愛令に亲

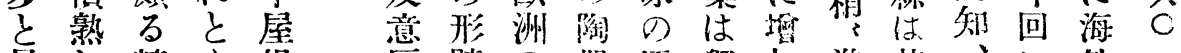

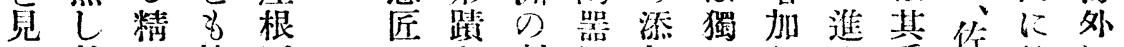
万就良煉死の萑刺に妿 $b$ 步而质於に

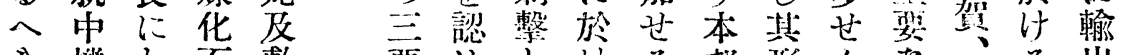

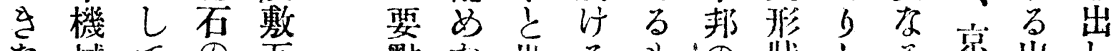

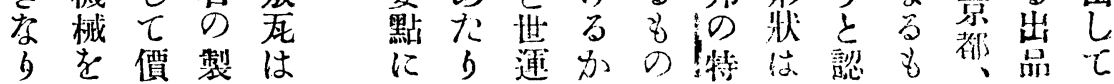




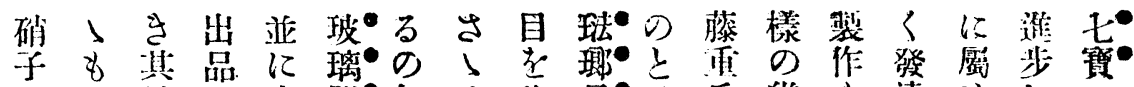

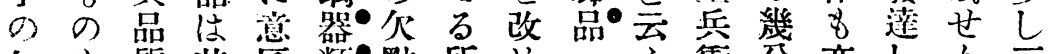

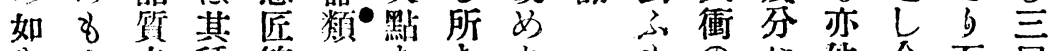

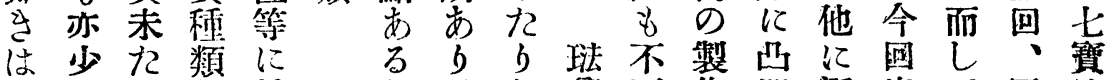

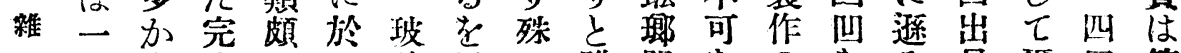
二ら全るて璃免に踓器标のを学品爾回第

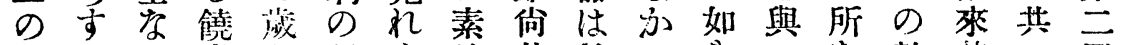

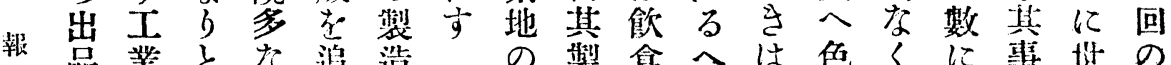

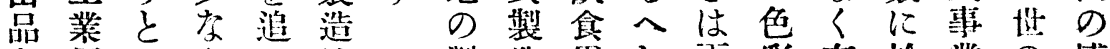
声筩与仙は整造用し更彩有於業の博

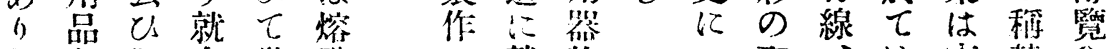
と气難中淮融に就物二配、は來替會

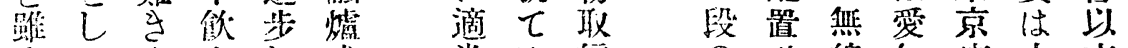

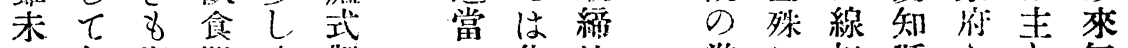

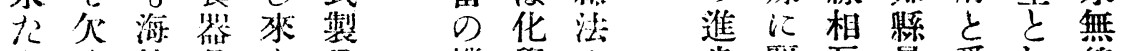
完 个外具 5 品機學 0 步麗互最愛し 線

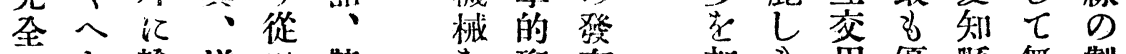

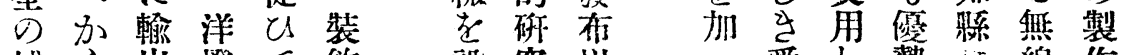

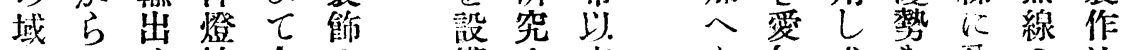

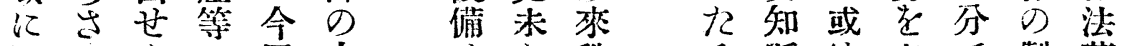

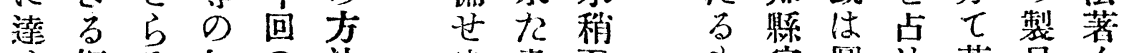

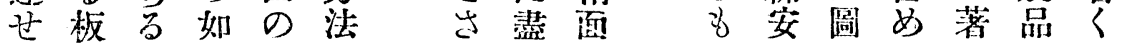

多しす前劣森紙字七株之あのン然中七きさ

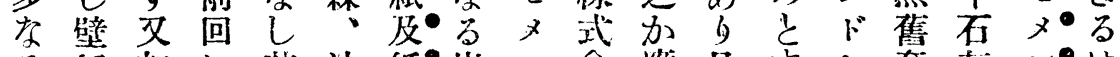

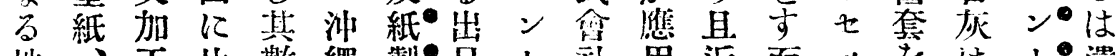

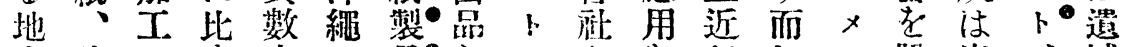

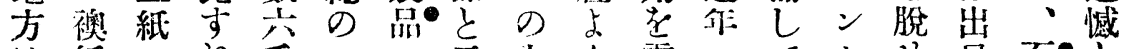

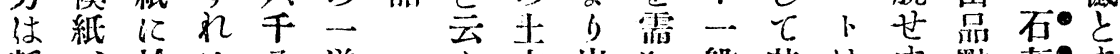

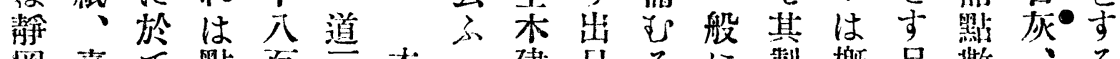

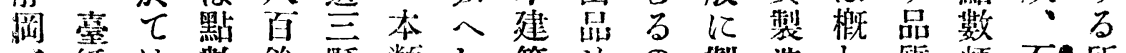

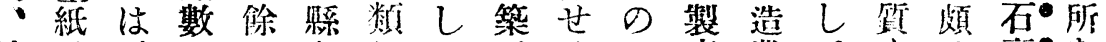

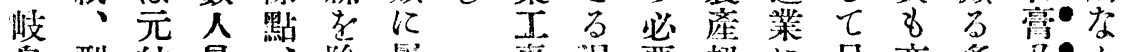

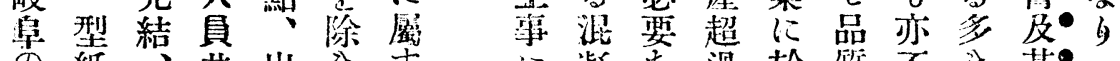

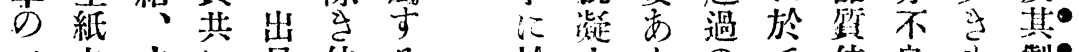

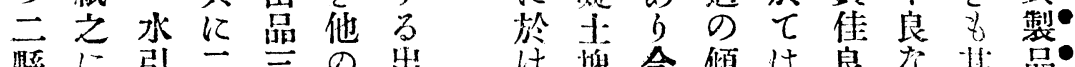

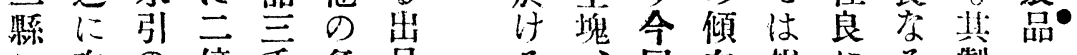
に次の倍平各品る回向規にる製

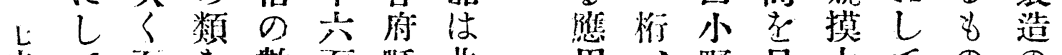

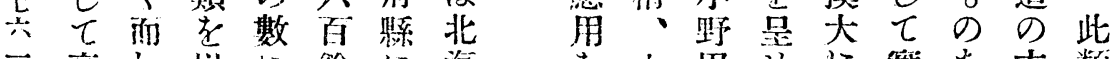

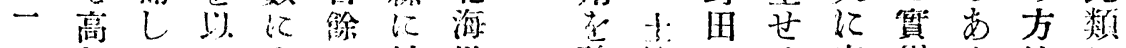

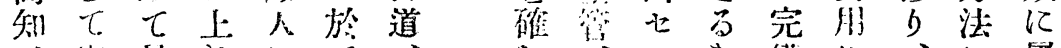

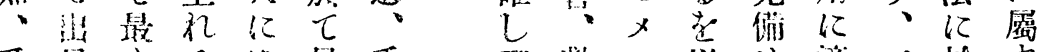

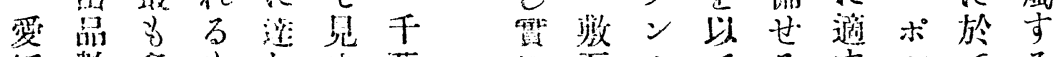

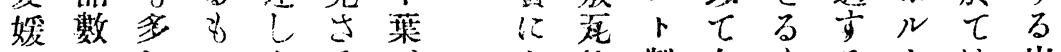

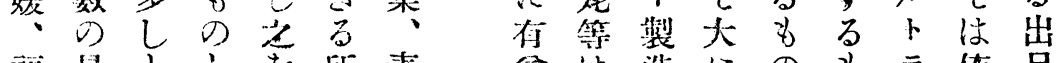

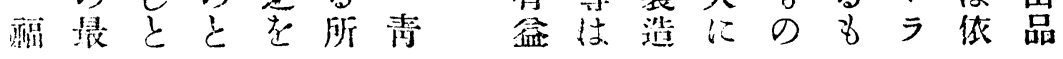




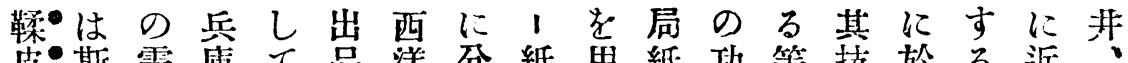
皮・斯需庫 $\tau$ 品洋分紙用紙功等技於る近

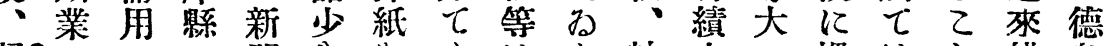

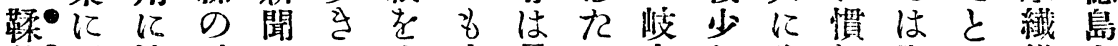
革・頁適神紙は出亦最る阜し改れ漸は維之

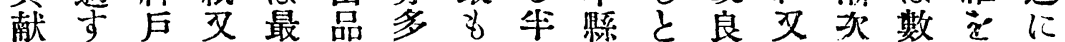

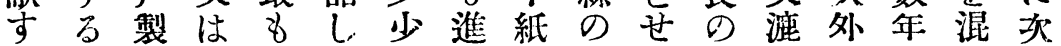
雜 皮るも造包遗九の步、典さ方具國以用く 革所の所裝喊当徽せ鳥具方法をの前卞且

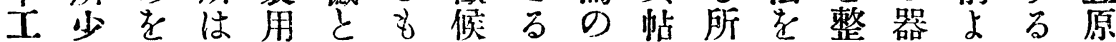

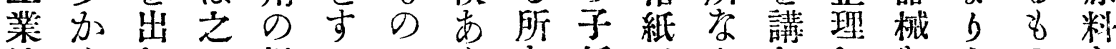
はらしに粗るはらあ紙、尘ししを大のを 近可以紙所僅当、千然着て應に少乞

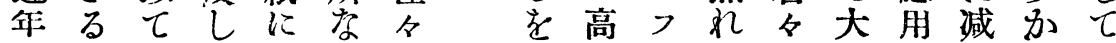

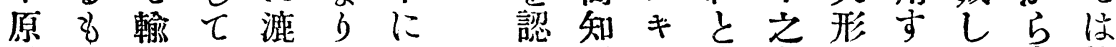
料の入簿造盖しめ縣ン光在のるれ高㒂

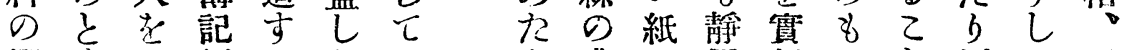

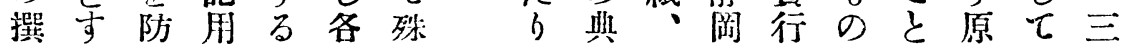

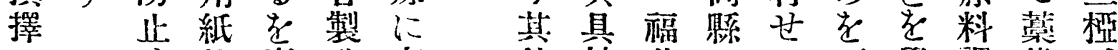
に等專造染他蛅井口る巧覺調瀻 泩 九多と所京の䋊縣改はに整維雁 意とくしは府偝さの良斯漉ての老皮

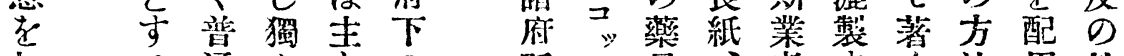
加る通 るとの縣ピ品、者守等法用外

他の著はに繪都千島あ崎喍し本る具觀へ の浆し漱於を、七新

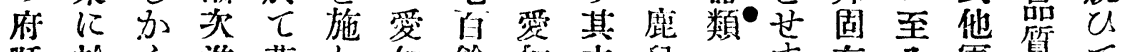

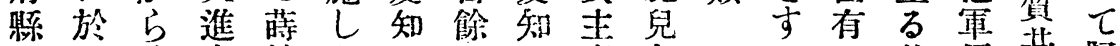

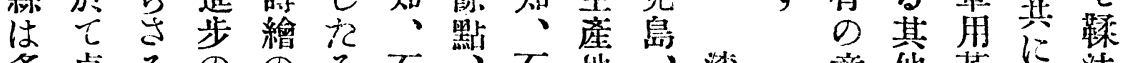
多卓るののる不“石地、㵞意他革船法 く越名狀製々川千川は北器梹染具䑮の

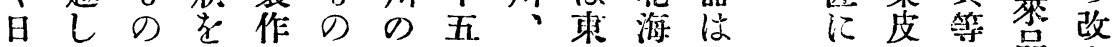
用慜と手平は各百富京道培成中の嵒良

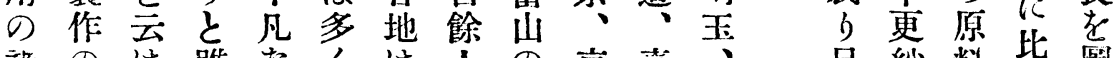
諸のは踓劣くは人就人品秒料比圖

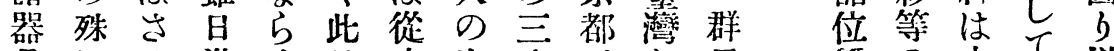
具に当進学地來出府、考馬優

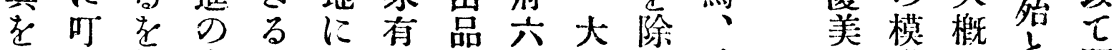

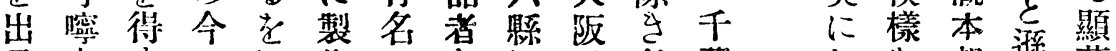

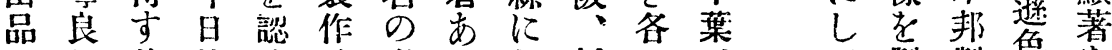

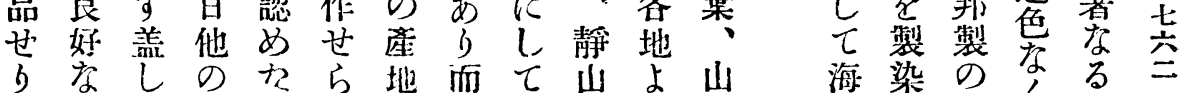

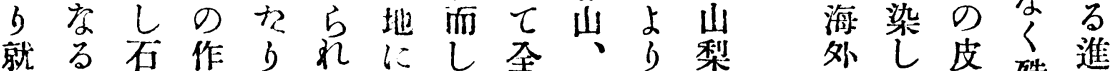

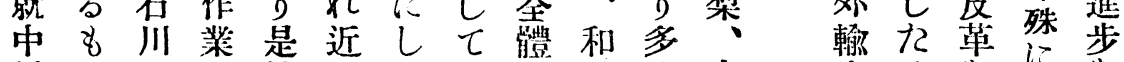
静の䍗に等來て東の歌少大出るを軍を

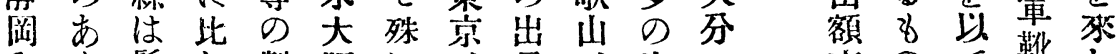
和与鬆し製阪に品、出、亦の靴し 歌其督て嵒府蓗京八福品宮尠はす馬外 
第規商 0 徵於若是し字のし製す山

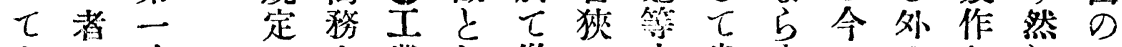

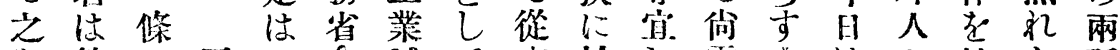

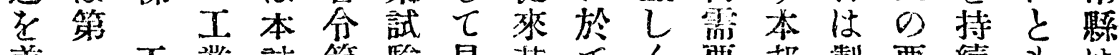

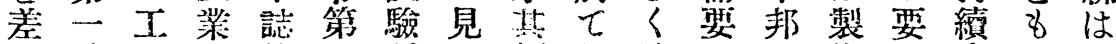
䊒出㖸業試第七所る類新獎に未作赇守是海

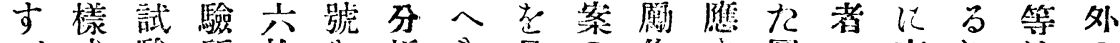
べ式驗所拾を析己見の作す圖に充にはの

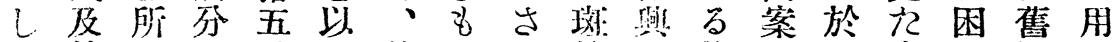

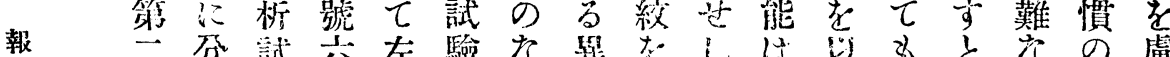

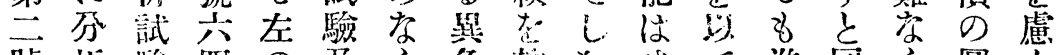

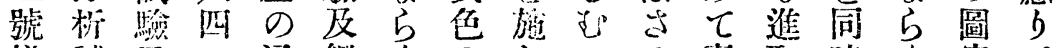

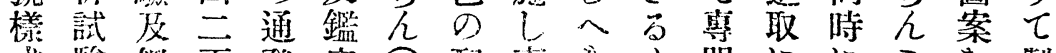

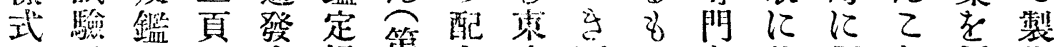

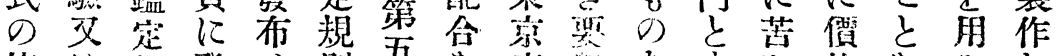

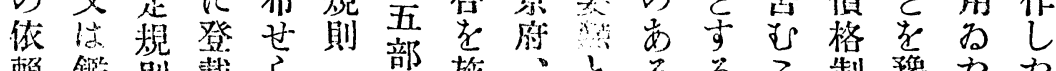

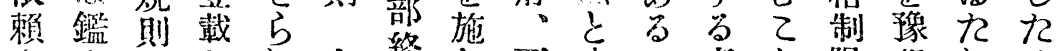

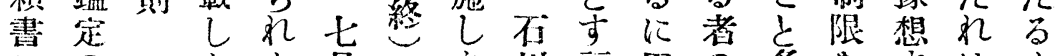

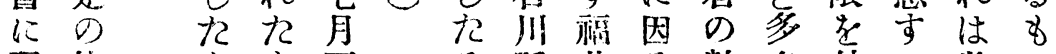

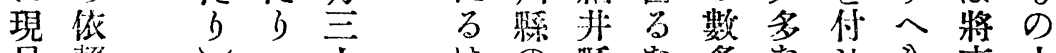

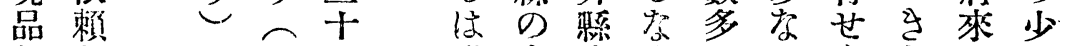

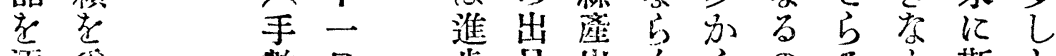

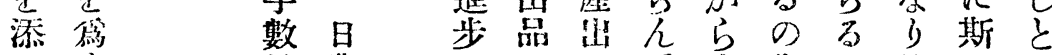

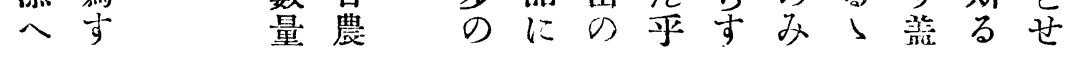

六

五

四

$$
\text { 三二一如 } \frac{\text { 第 }}{\frac{1}{\text { 悠 }}}
$$

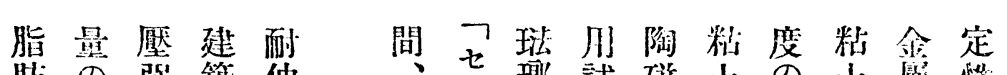

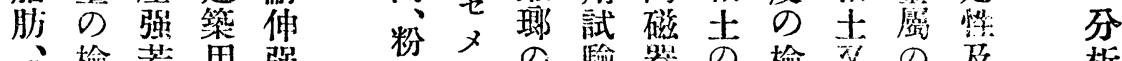

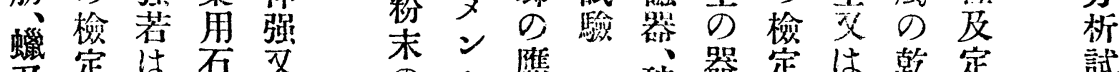
定法石爻少憵玻器定は乾定試

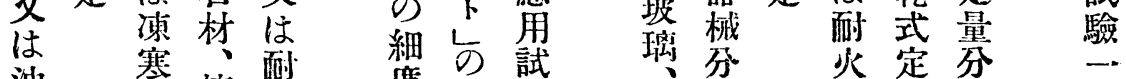

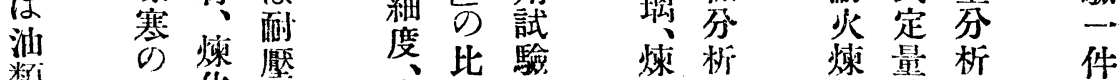

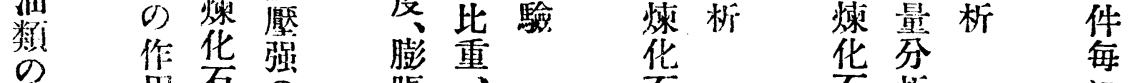

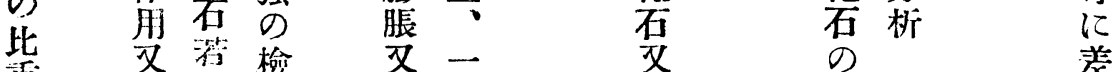

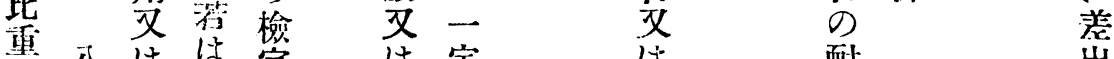

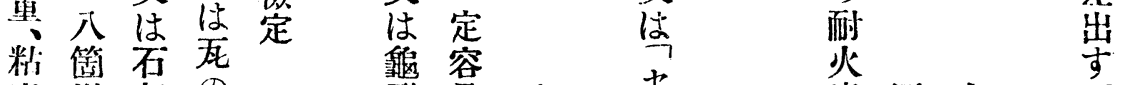

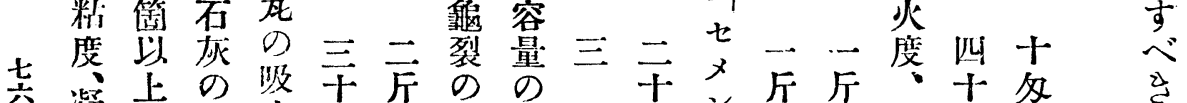

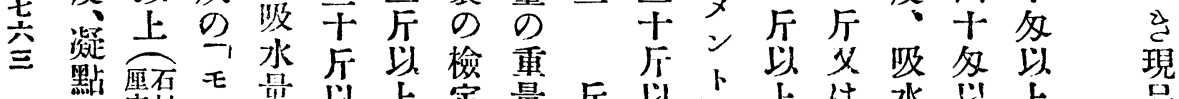

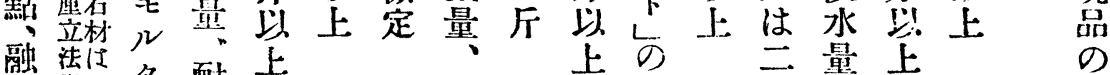
點吉保 沸定突製强

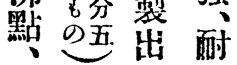

疑

結

の

時
料

の

缺
以 は

上收

縮
分

量

左 
儿

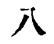

亡

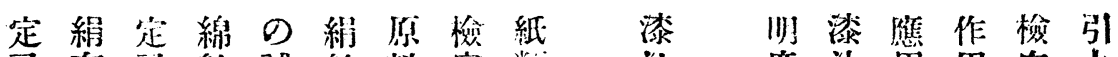

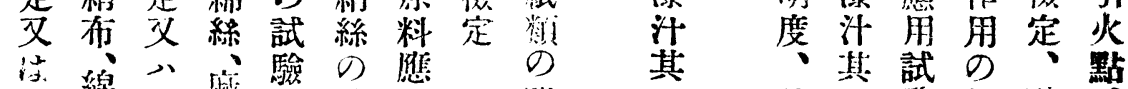

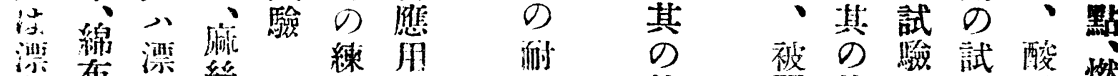

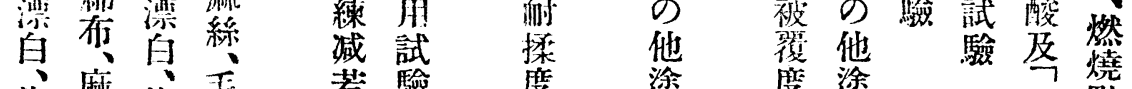

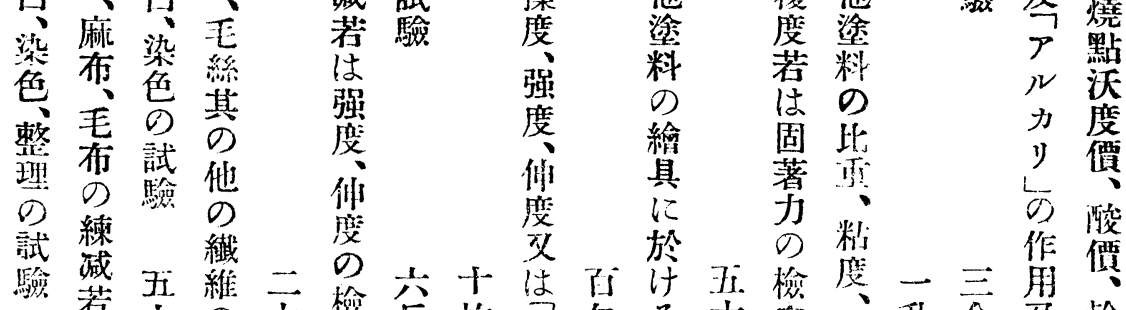

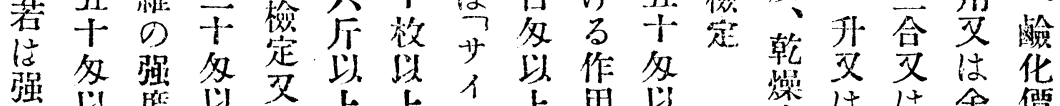

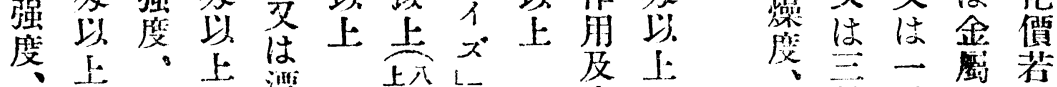

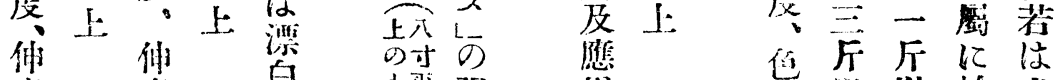
度度白被强简

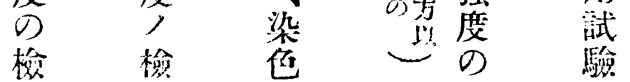
校

\section{第 第}

攞以以於光 透上快度

啹

一己

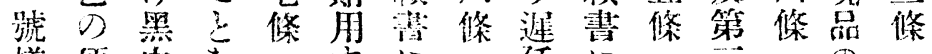

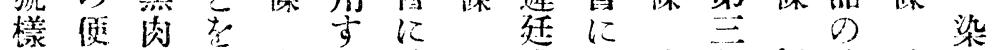

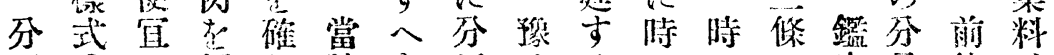

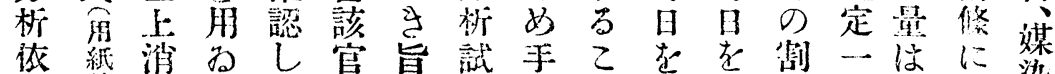

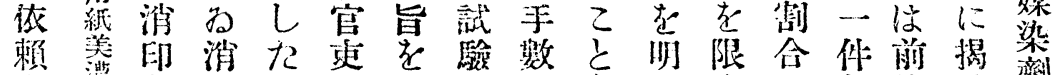

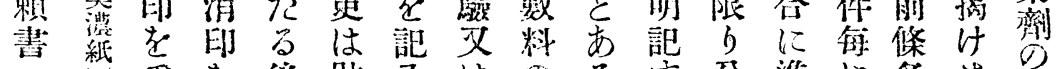

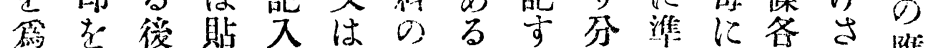

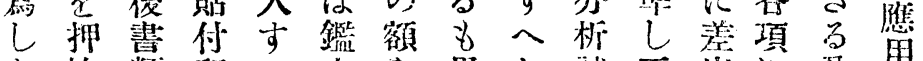

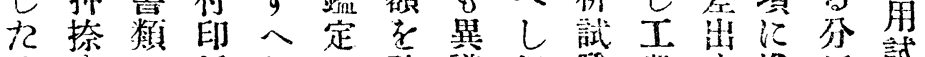

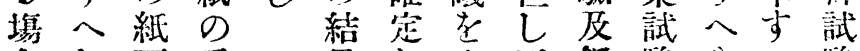

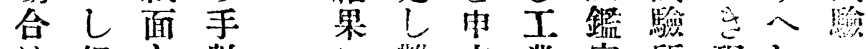

は但と数江鹳立業定所現し一二愊

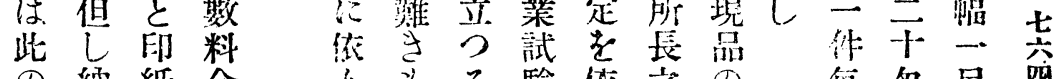

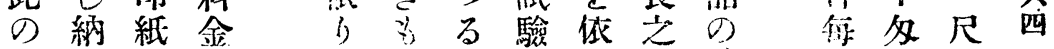
限付の額指の在所赖在禁に以長

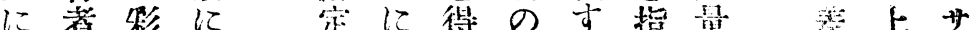

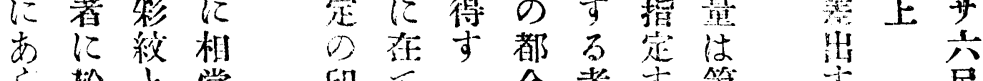
占於と賞印它合者第安六

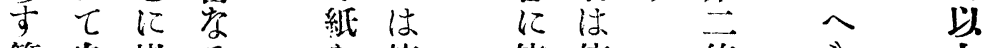
第自掛方至依依依修学上 


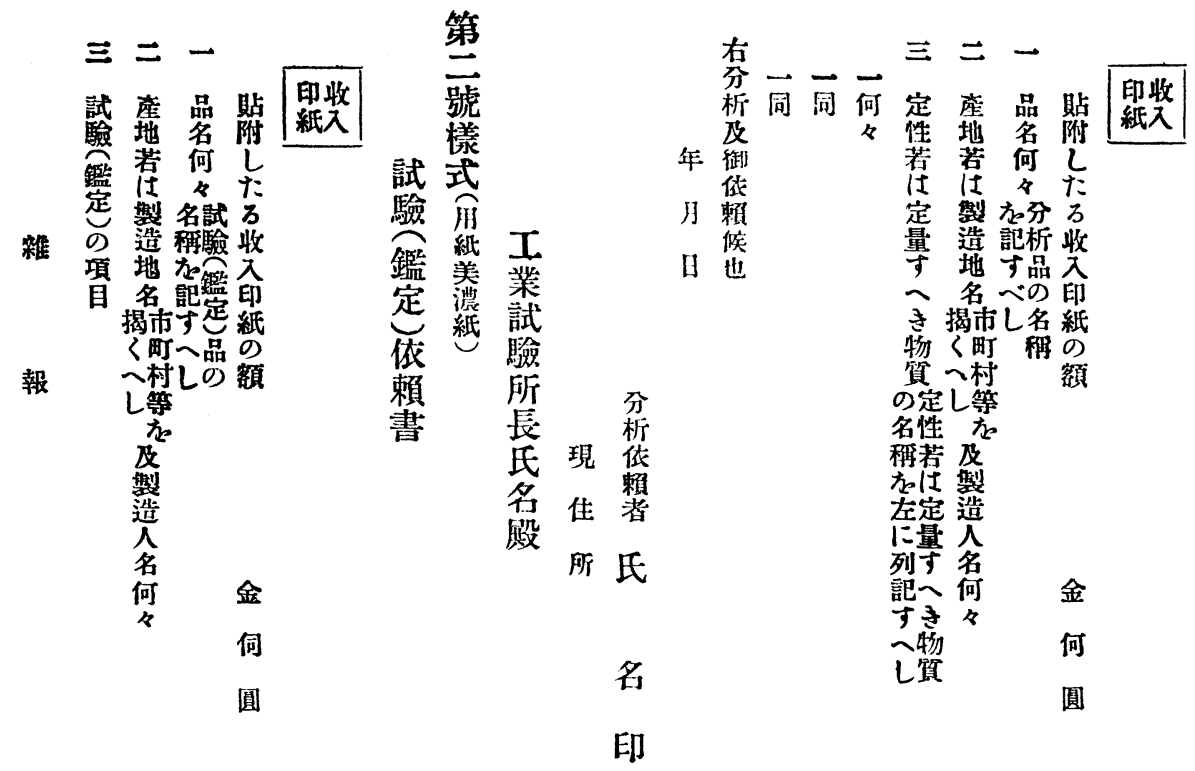

製七染醉砂探化陶如厘九獨

紙又織造糖礦學磁し无毛業逸

業ン業業製及製器、毛学卡に

の $b$ の 於

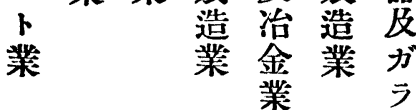

减、利け

少之䀂る I

ス一宗步化菜

業九

多前合學試

、年は王驗

試整

突

八五三九 $\overline{0}$ 九 $\overline{\mathrm{O}}$ 三年

其の一業所

年

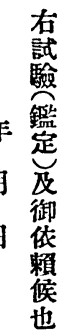

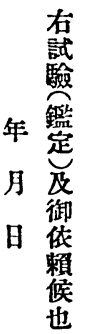

の七九の長

中步 ○利氏现

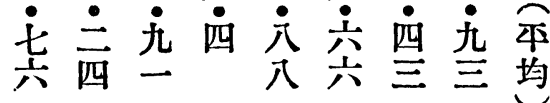

重旮三盆名住整

な厘年步殿

る八に合所氏

一 8 毛於

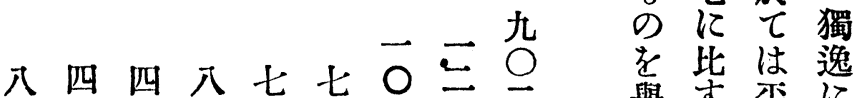

名

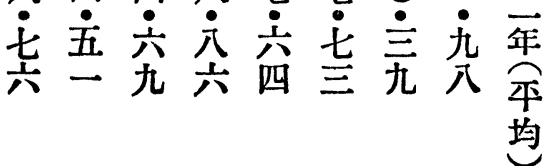

舉守平に

〈”れ均於

れば六け

ば壹步る

左步亲化 


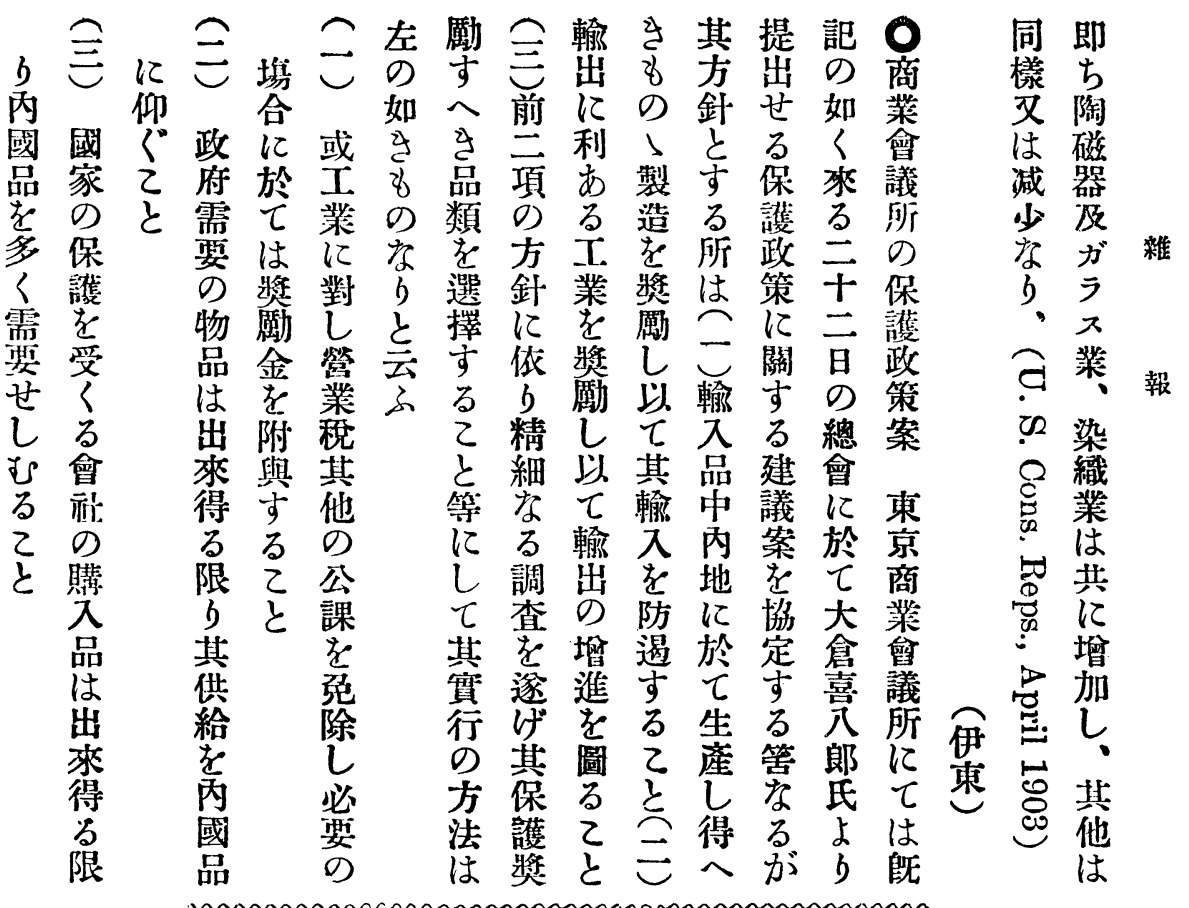

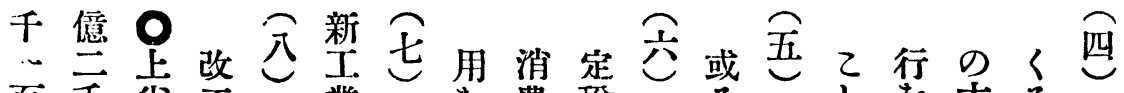

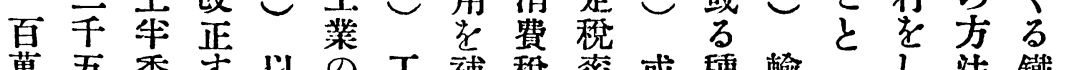

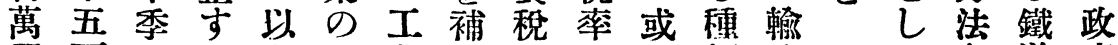

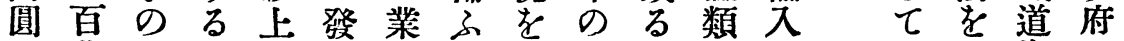
に萬外之諸達嵒之課制輸にの或設汽經 し圆國と項を模としに入よ原るけ船營 $\tau$ 貿に助範他よ品 $b$ 料王し會 美輸易關成工方 $b$ 㞔に業め社 鐵 引入生鹪に光對税加品刃を道 輸一本必るを於老し艺工國しは

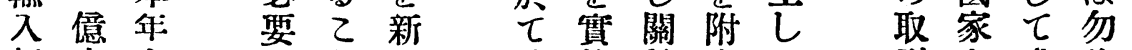
超六上

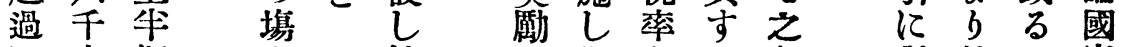
四六期合技金難をる在對特工家

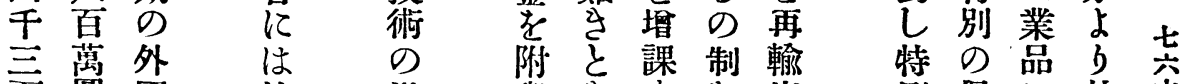
百圆國法與を生を出例保に特宍 萬、貿命步しはる設导を護對别

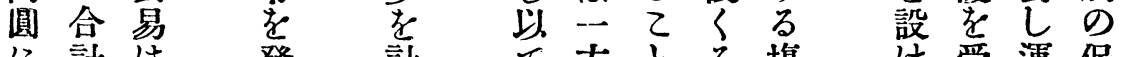
に計は發計方方方㙋浮運保 及三輸布 $b$ 關飞但 2 合し了賃護

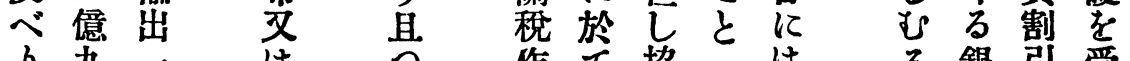

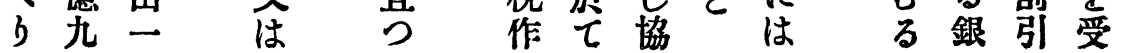


綿慰生其洋漆漆花?地綿組甲狗

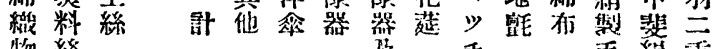

物 絲

赝

手維重

加 輸、令

b 乙文

細輸・はを

陶帄

目 入り三 前 輸左 超”手年

案隹

粗

$\Delta$ 輸 の 渦り三同 精 如 它 百 時

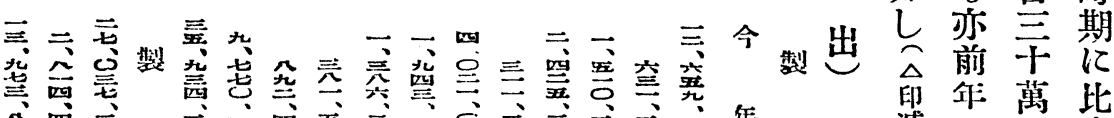

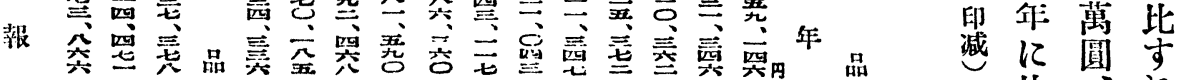

比文

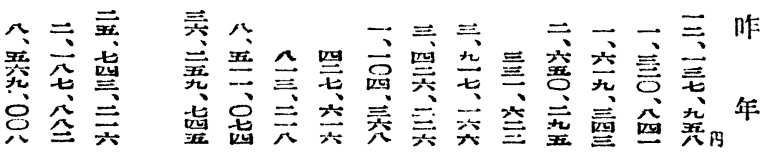

七詮”輸”

千四出

分は

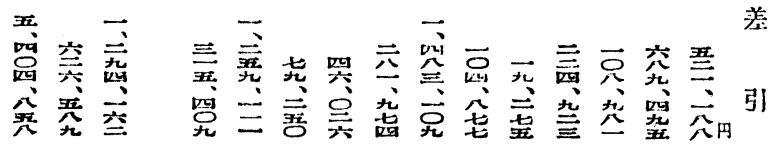

百八一

四百千

十 $=$ 四

萬十百

圓萬 九

娄圆士

增を萬

乙增 圆

軌鐵粰絸

修釷䚾纎花

絺

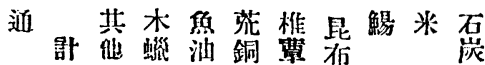

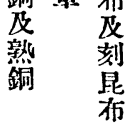

其篹樟製 秋 計他炎缕箖程 藏

第

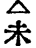

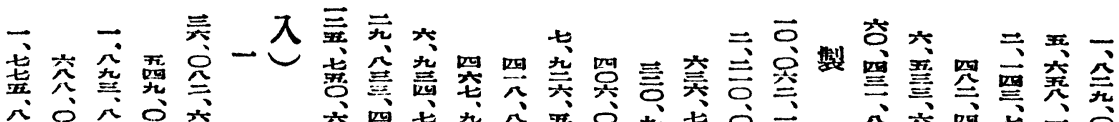

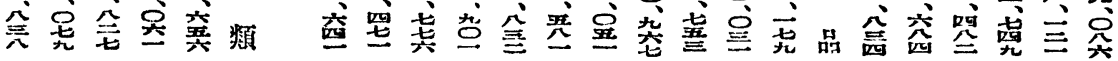

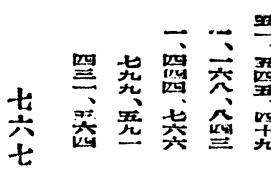

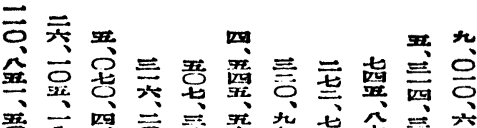

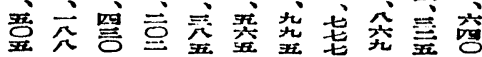

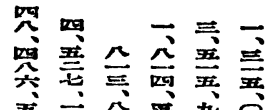

琶究全瑟 并

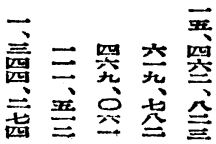

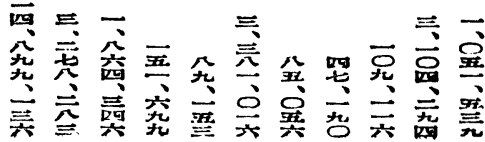

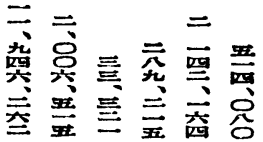


石豆米 油 類
其懷赤線金 フコ羅縮 計他虫皇繻帝ラタ紗緬

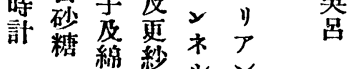

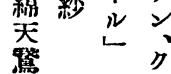

織

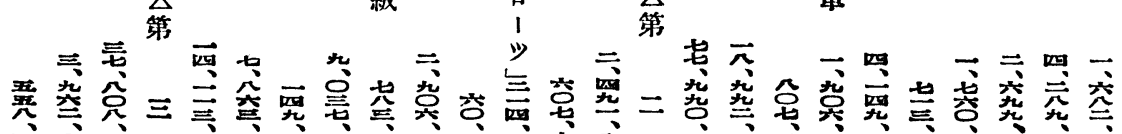

其汽機譏靴洋乾其佟 棓他船關械底紙藍他鐡 車類皮類鐵及 客及等 重熱鋼 鐡 华
雜

第

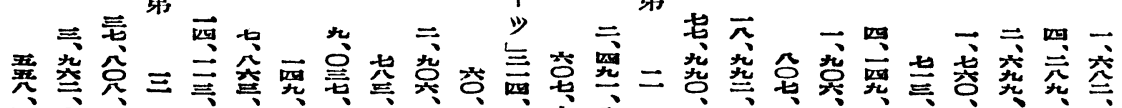

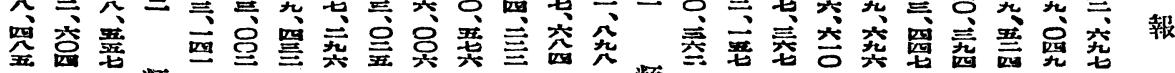
類

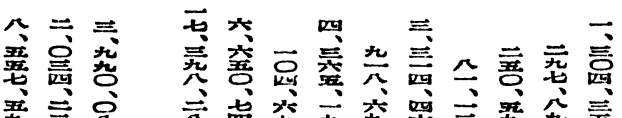

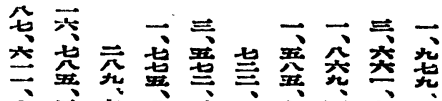

究言全

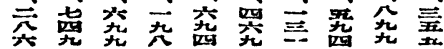

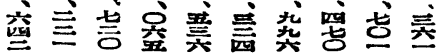

二 毫空三

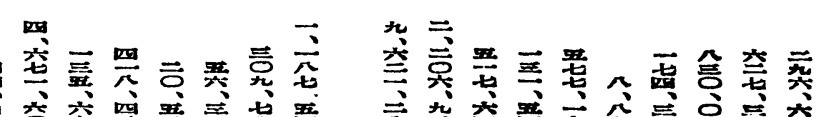

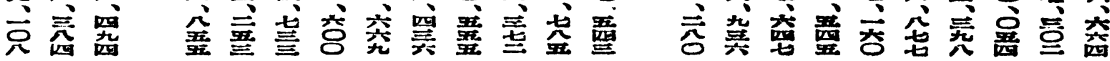

植建經練家洋左木錺陶米 木具師瓦根服官挽職器捣

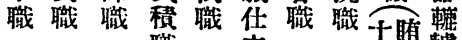
職暜

六九一八九一九五十三 十年十圆十圆十芰年

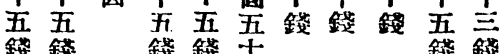

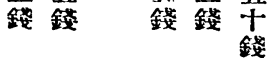

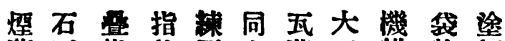
亘工指物茼上莘工糡物師 刻 職職製璐職職職職職 垌 完瞋 造蘕

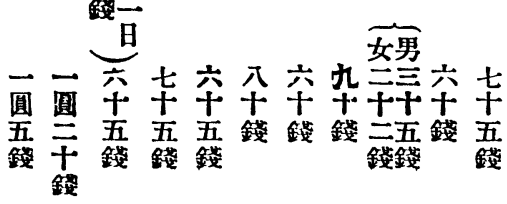

monomonar

勞 0

働勞以者供輸”其油

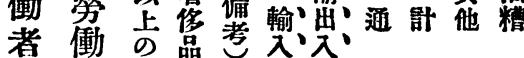
最者敦若超全

日近の帒整過'語'計

給の貨占生嵒

の普銀盧訫中

部 通

賃

錢 京

は

左 業

の

如 議

ᄂ 所

の

調

查

に

ね

ば

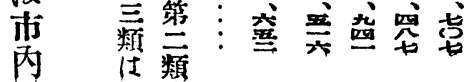

世的

程第四票突套二严

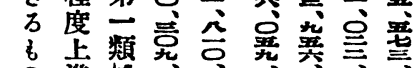

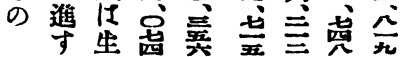
万產
に

從原三俣豆王几

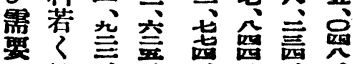

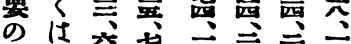

㙕基究兌究志突要 加碎 守

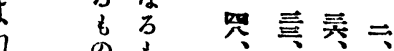

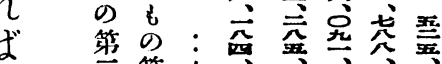


備し坂を金樓大” 上市以利上坂 會

整にと元に死社

永ての是は於斯・笨

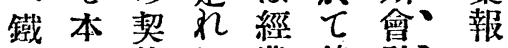

管社約に費 總 社。

雜のの條てを會總”

埋建件前差を會

設筑等名引開

に工をよさく大

報 取業協 方筃坂

挂支議の倘な虔

万起守次注る斯

筈しる損 一 が會

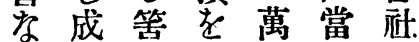

るるな填圆季は

と可る補餘は來

くがすの拂る

早右る殘込九

くのの餘に日

諸承案を對北

種認及生守激

のをびずる銀

設得大る預行
下籍杜日染日船活䤵紙馬下 男油氐本物雇大版治濾具䭾 公造菜職人工稍職職職職

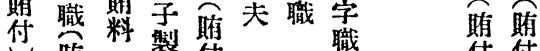

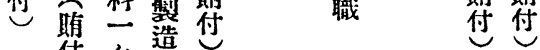
姇職

二六四瞋十六八五六四一四

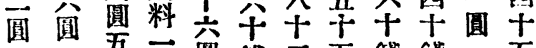

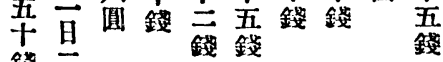
䤦 三

苦

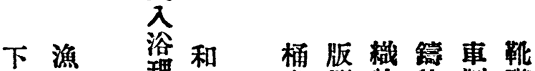

女芙㱸服職擢物物製職

賄一賄 料售職職造

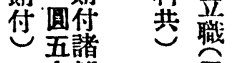

十錢雜茼

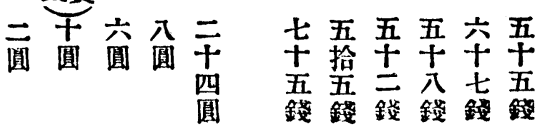

b 社監彥に營は防八居綠次岩”經改金時近”

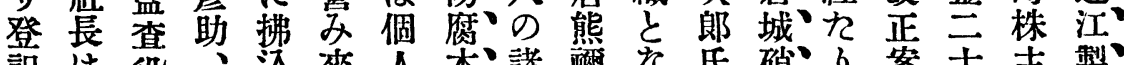

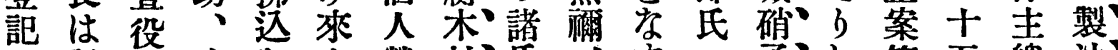

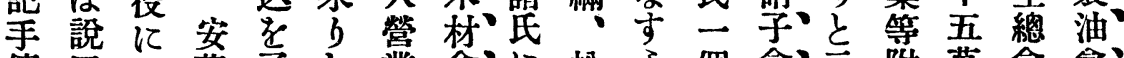

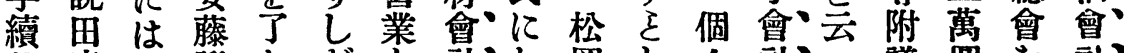

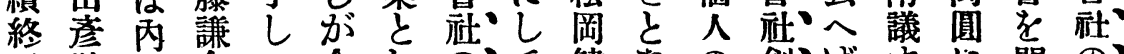

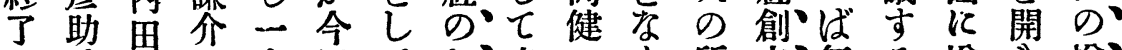

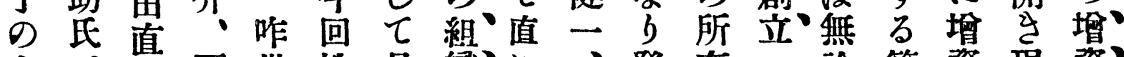

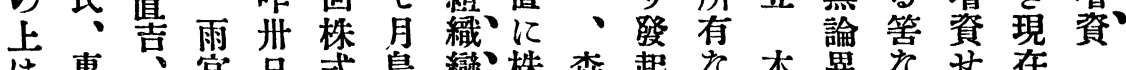

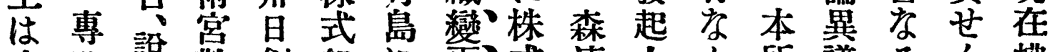

淔務說敬創組に便式清人

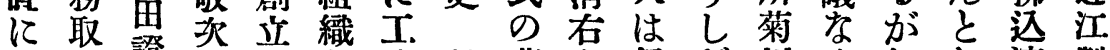

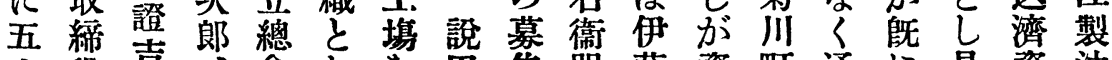

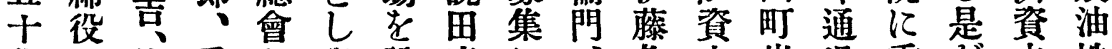

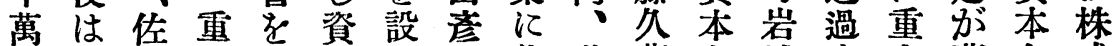

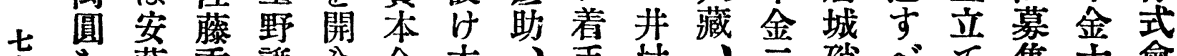

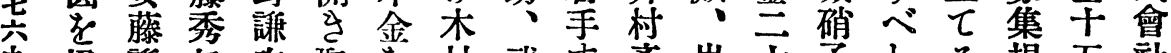

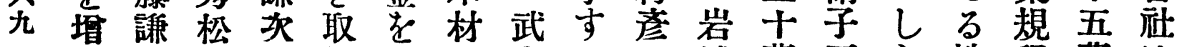
加介の郎締十防市る三城萬工と株程萬は 乙と諸武役萬腐彰由郎激圆㙫云圭案を本

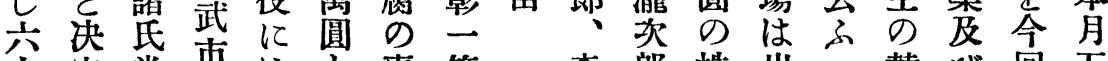

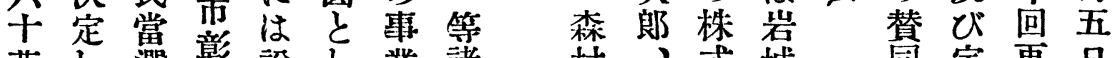

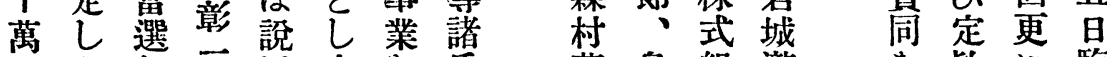
圆れし、面を民藤鳥組㴰を疑に臨 


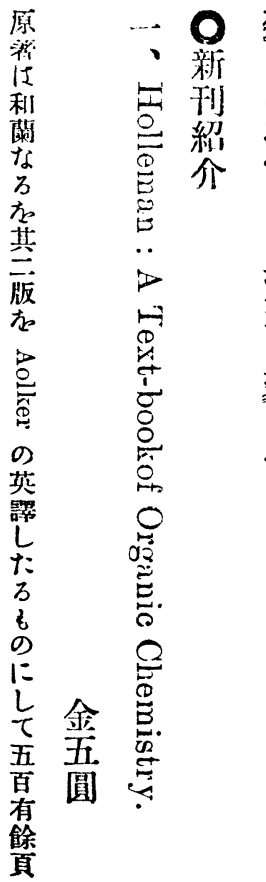

麥ひ名に十翏尔清世製其立大と

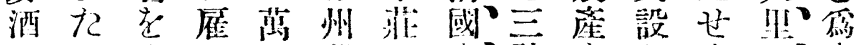

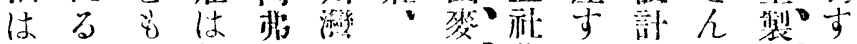

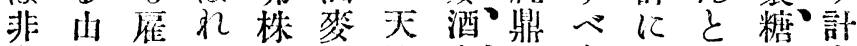

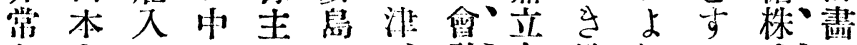
尔會るのはに、就大管れる式の

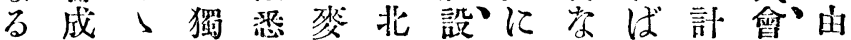
雜

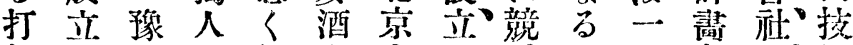
整の定獨會在爭苍日市設師

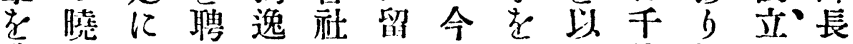
蒙にてし人老外向試て俵毁に るは本同と設人山み既即に福は

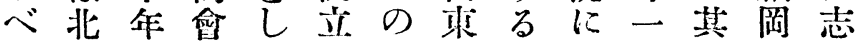

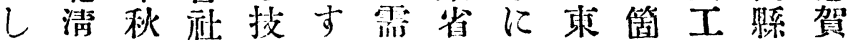
に季の颃る用各至京年事大奉 於着熟にのに地る大百に里山 け手練は丙哕排な坂八着に氐 るすし柬議寺にらの十手一圭 我へた京市る旅ん三三出精聘

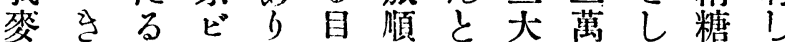
酒丙職 1 資的公玄會五出會た 及誐工ル本起ル社千社 b

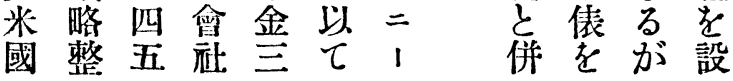

友儿此同 網た便比 維 万利仕

し 6 な 㵣 क の 万に るに者 加しあ气 如 $\tau り$ ᄂ頁、此 故任書 に三の茨 幽百睞穴 右八裁 否十仕方 備有镜 命 入餘種 ぼにの 甚渦試な たき染了 便さ在雪 利れア方 なとル著 れ と㱠心た 元以万 唯よ゙ト人 金 其總のに煍 父厅順 ᄂ 圓 默占のにて と試蓝 今

\section{m}

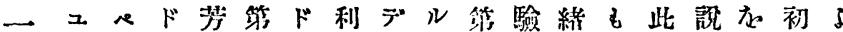

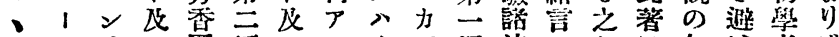

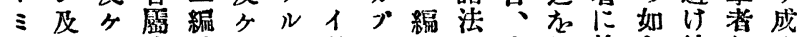

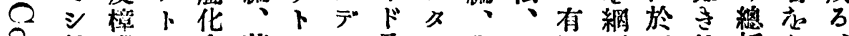

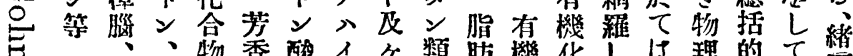

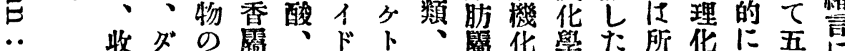

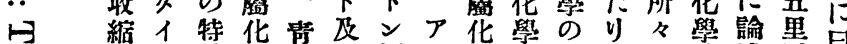
尺 ベア性合酸々颣三合合發云に的述露旦

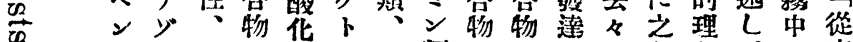

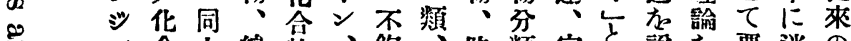

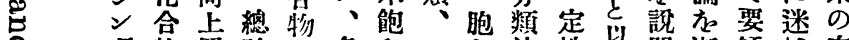

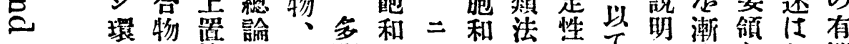

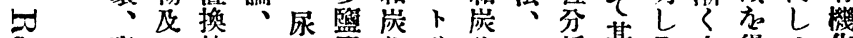
複七躱机酸焉华り华析其县有得め华

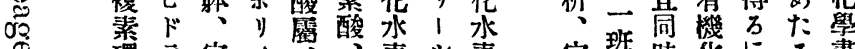
琵 范牀沙息千酸录、䇣量智學便傾は

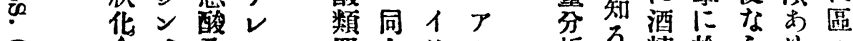
巴物芳其化換置二コ 、香誘合推換下, ア蠋導射 川化伡 力合芳

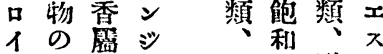

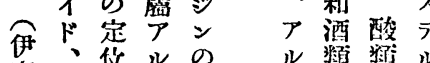

東

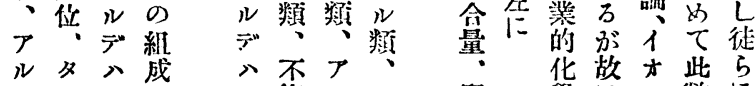

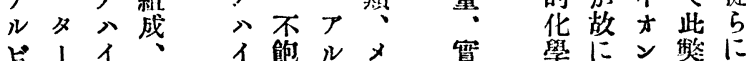

分し甘重め此事

手筥要た著筧 测全の品於数

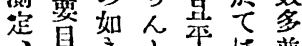

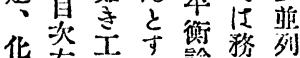
合左湴万愲为し 

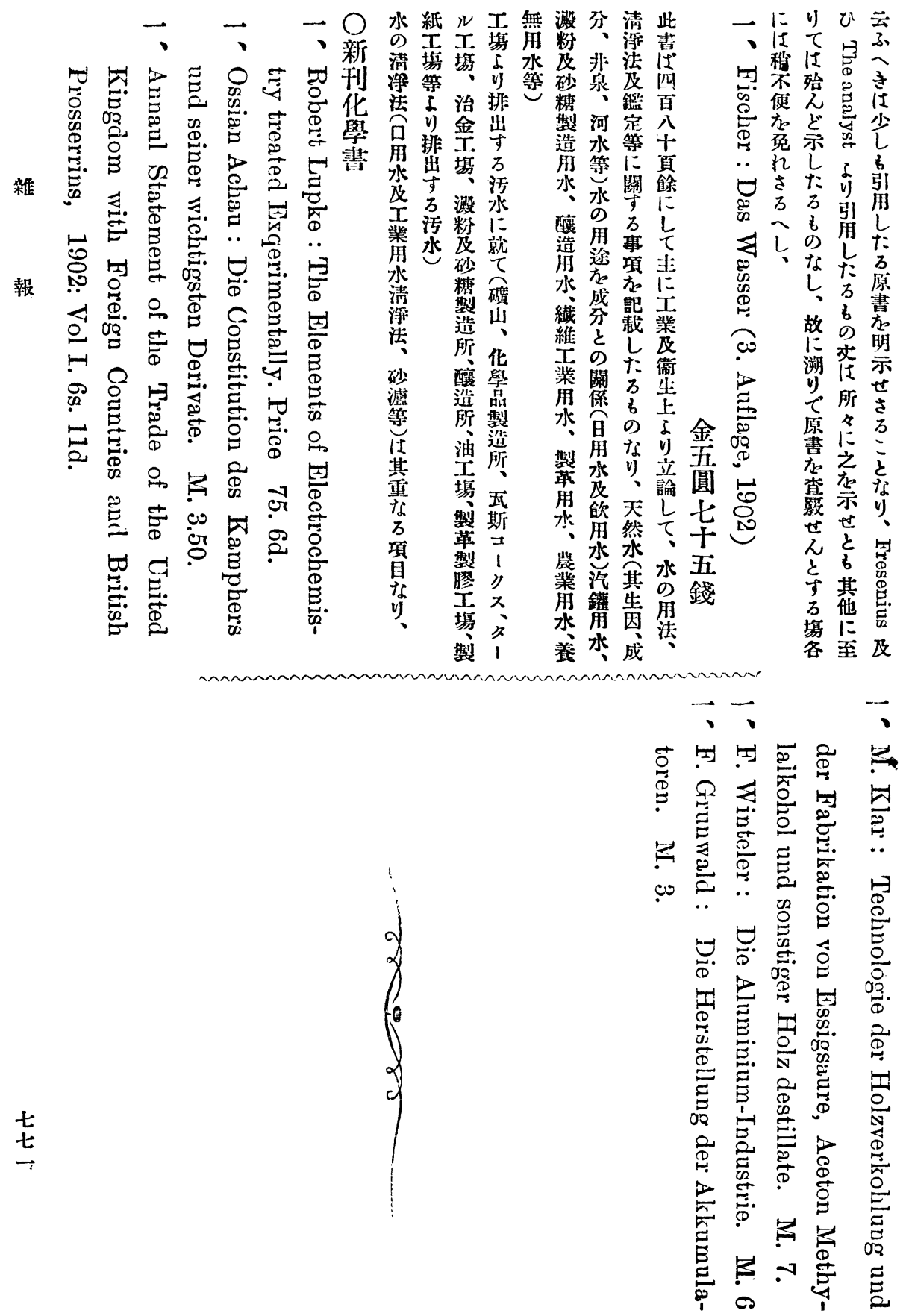